\title{
Molecular Insights into Mental Retardation: Multiple Functions for the Fragile X Mental Retardation Protein?
}

\author{
Francesca Zalfa ${ }^{1}$ and Claudia Bagni* ${ }^{\star 1,2}$ \\ ${ }^{1}$ Dipartimento di Biologia, Università di Roma "Tor Vergata". \\ Via della Ricerca Scientifica. 00133 Roma, Italy. \\ ${ }^{2}$ Istituto di Farmacologia, Fondazione Santa Lucia, IRCCS. \\ Via Ardeatina, 306 Roma, Italy
}

\begin{abstract}
Mental retardation is a frequent cause of intellectual and physical impairment. Several genes associated with mental retardation have been mapped to the $X$ chromosome, among them, there is FMR1. The absence of or mutation in the Fragile Mental Retardation Protein, FMRP, is responsible for the Fragile $X$ syndrome. FMRP is an RNA binding protein that shuttles between the nucleus and the cytoplasm. FMRP binds to several mRNAs including its own mRNA at a sequence region containing a $\mathrm{G}$ quartet structure. Some of the candidate downstream genes recently identified encode for synaptic proteins. Neuronal studies indicate that FMRP is located at synapses and loss of FMRP affects synaptic plasticity. At the synapses, FMRP acts as a translational repressor and in particular regulates translation of specific dendritic mRNAs, some of which encode cytoskeletal proteins and signal transduction molecules. This action occurs via a ribonucleoprotein complex that includes a small dendritic non-coding neuronal RNA that determines the specificity of FMRP function via a novel mechanism of translational repression. Since local protein synthesis is required for synaptic development and function, this role of FMRP likely underlies some of the behavioural and developmental symptoms of FRAXA patients. Finally we review recent work on the Drosophila system that connects cytoskeleton remodelling and FMRP function.
\end{abstract}

\section{Introduction}

Mental retardation is defined as an impairment that affects brain function and that reflects functional deficits in adaptive behaviour such as interaction with people and daily living. Usually it is manifested before 18 years of age (Stevenson et al., 2000). Defining features of mental retardation include an overall intelligence quotient (IQ) of less than 70 . The causes of mental retardation are heterogeneous and include genetic as well as non-genetic factors like infection

*For correspondence. Email Bagni@uniroma2.it. during pregnancy and meningitis. The characterised genetic causes of mental retardation that have been well described to now include chromosomal abnormalities and monogenic diseases. However, a significant percentage of cases with mild retardation $(50<I Q<70)$ remain unexplained. As suggested by several researchers in the field, most of the mild cases probably involve a combination of multigenic and environmental factors (Chelly and Mandel, 2001). An estimated $20-30 \%$ of mental retardation cases are thought to be due to X-linked defects (for review, see Stevenson et al., 2000). The most frequent cause of inherited mental retardation is represented by the Fragile $X$ syndrome (1 in 4000 males and 1 in 6000 females) initially discovered by Martin and Bell in 1943 (Martin and Bell, 1943).

Patients with the Fragile $X$ syndrome exhibit mental retardation ranging from severe (IQ 20) to moderate (IQ 60 ), autistic behaviour and some physical features, like elongated face, large ears, joint laxity and macroorchidism (for reviews see Bardoni and Mandel, 2002; Oostra, 2002; O'Donnell and Warren, 2002). Interestingly, patients with this syndrome exhibit a quite variable social behaviour. They can learn to perform better for their daily living and with practise can improve their physical and intellectual attitude, which agrees with the positive effects of experience, including physical exercise, on the development of mammalian brains. Remarkably, some Fragile $X$ patients have also participated to a marathon to the north pole (www.progettofilippide.cnr.it).

The syndrome results from the absence or mutation in the FMRP protein, the protein encoded by the FMR1 gene. FMRP is widely expressed in foetal and adult tissues, with the most abundant level of expression in brain and testes (Devys et al., 1993).

FMRP contains a nuclear localization and a nuclear export signal, which has led to hypothesis that it is involved in mRNA transport from the nucleus to the cytoplasm (Eberhart et al., 1996). The protein contains four RNA binding domains and has the ability to bind a whole series of mRNAs/RNAs (for reviews see Kaytor and Orr, 2001; Antar and Bassell, 2003). The FMRP ribonucleoprotein particle associates with ribosomes and it is thought to be involved in cytoplasmic transport, and/or translational control of the bound mRNAs. In mammalian neurons, it has been shown that FMRP acts as a regulator of protein synthesis at synaptic sites of dendrites probably promoting maturation of dendritic spines (Zalfa et al. 2003) while its Drosophila homologues seem to be also involved in axonal growth (Zhang et al., 2001; Morales et al., 2002). In agreement with this function the morphological anomaly in the brain of both FRAXA post-mortem patients and FMR1 
knockout mice appears to be limited to the presence of abnormal dendritic spines, which morphologies resemble that of early development (Hinton et al., 1991; Comery et al., 1997, Nimchinsky et al., 2001; Irwin et al., 2001).

In the last five years, the role of FMRP has been largely elucidated thanks to the joined efforts of many outstanding laboratories in the world. In this review, we will summarise the knowledge of the fragile $\mathrm{X}$ syndrome and FMRP protein in mammals and review work on the Drosophila model system that helps to link the molecular mechanism of cytoskeleton remodelling and the Fragile $X$ mental retardation protein. In this context we discuss our recent results concerning a new mechanism by which FMRP could regulate neuronal mRNA translation at synapses.

\section{Molecular-genetic basis and neuronal characteristics of the fragile $X$ syndrome}

The Fragile X syndrome was initially discovered in 1943 by Martin and Bell (Martin and Bell, 1943) who reported the first pedigree of a sex-linked form of mental retardation. During the 1970s, Lubs demonstrated its co-segregation with a cytogenetic abnormality of the X chromosome (Lubs, 1969) and finally Sutherland established the nature of this anomaly as a fragile site that can be induced under certain cell culture conditions (Sutherland, 1977). Only in 1991, the syndrome was shown to be associated with a massive trinucleotide repeat expansion within the gene named Fragile X mental retardation-1 (FMR1; Verkerk et al., 1991, Yu et al., 1991) and mapping and characterisation of the gene has brought in the last years new insights into the molecular mechanism of mental retardation.

$F M R 1$ is a highly conserved gene that is composed of 17 exons, spans about 40 kilobases $(\mathrm{kb})$ of DNA and encodes an mRNA of $3.9 \mathrm{~kb}$ (Figure 1). FMR1 can be alternatively spliced, which does not appear to be tissuespecific (Ashley et al., 1993; Eichler et al., 1993; Verkerk et al., 1993). FMRP is widely expressed, with the most abundant expression levels observed in brain and testes (Abitbol et al., 1993; Devys et al., 1993), the major organs affected in the Fragile $X$ syndrome. In a majority of cases (>95\% of patients), the Fragile $X$ syndrome is caused by expansion of a polymorphic CGG repeat located in the $5^{\prime}$ UTR of the gene. Based on the size of this expansion, it is possible to distinguish four principal types of alleles: normal (6-50 repeats), intermediate or "grey zone" ( 45-60 repeats), premutation ( $~ 55-200$ repeats), and full mutation (>200 repeats) alleles. The distinction between intermediate and premutation alleles is made by family history and repeat instability (Nolin et al. 2003; Figure 1). The full mutation-size expansions are associated with hypermethylation of the CGG repeats and the upstream CpG islands, which, most of the time, leads to transcriptional silencing of the gene and a severe physical and neurological phenotype (Verkek et al., 1991; Oberlè et al., 1991; Sutcliffe et al., 1992). However, rare atypical cases of Fragile $X$ syndrome have been reported that are not associated with an amplification of the trinucleotide repeat, but with deletions or single point mutations (Gedeon et al., 1992; Wohrle et al., 1992; De Bouelle et al., 1993; Meijer et al., 1994; Hirst et al., 1995; Milà et al., 2000).
Premutation alleles are highly unstable and tend to expand to the full mutation when transmitted. The larger the premutation repeat is, the more likely it will expand to the full mutation, and this occurs only when the premutation is transmitted from a female (Malter et al., 1997). The frequency of the premutation (carriers) is estimated to be 1 in 760 males and 1 in 260 female (Rousseau et al., 1995). At the molecular level, individuals with premutation alleles show elevated FMR1 mRNA levels (2-10 times higher that normal) but normal or reduced FMRP levels (Tassone et al., 2000a, 2000b). This discrepancy can be explained by a reduced translational efficiency of the mRNA due to the triplet repeat in the 5'UTR (Tassone et al., 2000a, 2000b; Kenneson et al., 2001; Primerano et al., 2002; Figure 1). Male premutation carriers have a different phenotype that has been recently discovered (Hagerman et al., 2001; Greco et al., 2002) and it is still mostly not understood (see below).

Since the mental retardation is the most important feature of the Fragile $X$ patients, the brain has been most intensively studied in affected humans and mice models. Generally, the brain shows no gross defects. However, observations made using Golgi-Kopsch-stained cerebral cortices from post-mortem Fragile $\mathrm{X}$ brains have described dendritic spine morphologies that resemble those observed early in development. It is noteworthy that dendritic spine development is slowed in the cerebral cortex of FMR1 KO showing a temporarily increased percentage of long thin dendritic processes. Both affected humans and FMR1 KO mice indeed exhibit a similar dendritic characteristics (Hinton et al., 1991; Comery et al., 1997; Irwin et al., 2001; Nimchinsky et al., 2001).

How loss of FMRP affects synaptic function and leads to abnormal cognitive functions it is still an open question. In the last three years, there have been many albeit partial answers to this problem, and a picture starts to emerge from the puzzle so that in the future it will hopefully be possible to unravel the aetiology of the Fragile $\mathrm{X}$ syndrome. This will not only provide insights into the molecular basis of the Fragile $X$ syndrome but also into learning and cognition in general.

\section{Structural and functional domains of FMRP}

FMRP is part of a small protein family that also includes the Fragile-X-related proteins FXR1P and FXR2P. The three proteins share the same domain structure and exhibit more than $60 \%$ amino acid identity to each other (Siomi et al., 1995; Zhang et al., 1995). The domain structure consists mostly of an array of four RNA-binding motifs (Figure 2): two ribonucleoprotein $\mathrm{K}$ homology domains ( $\mathrm{KH}$ domains), a cluster of arginine and glycine residues (RGG box), and a new RNA-binding domain present in the $\mathrm{N}$-terminal region of the protein (Adinolfi et al., 1999a; Adinolfi et al., 2003). Consistent with this domain structure, FMRP binds to RNA homopolymers as well as to a subset of brain transcripts (Ashely et al., 1993; Adinolfi et al., 1999a; Sung et al., 2000; Brawn et al., 2001; Darnell et al., 2001; Miyashiro et al., 2003). Considering the wide class of possible target mRNAs that have been recently described (see below), we think it is important to discuss the current knowledge 


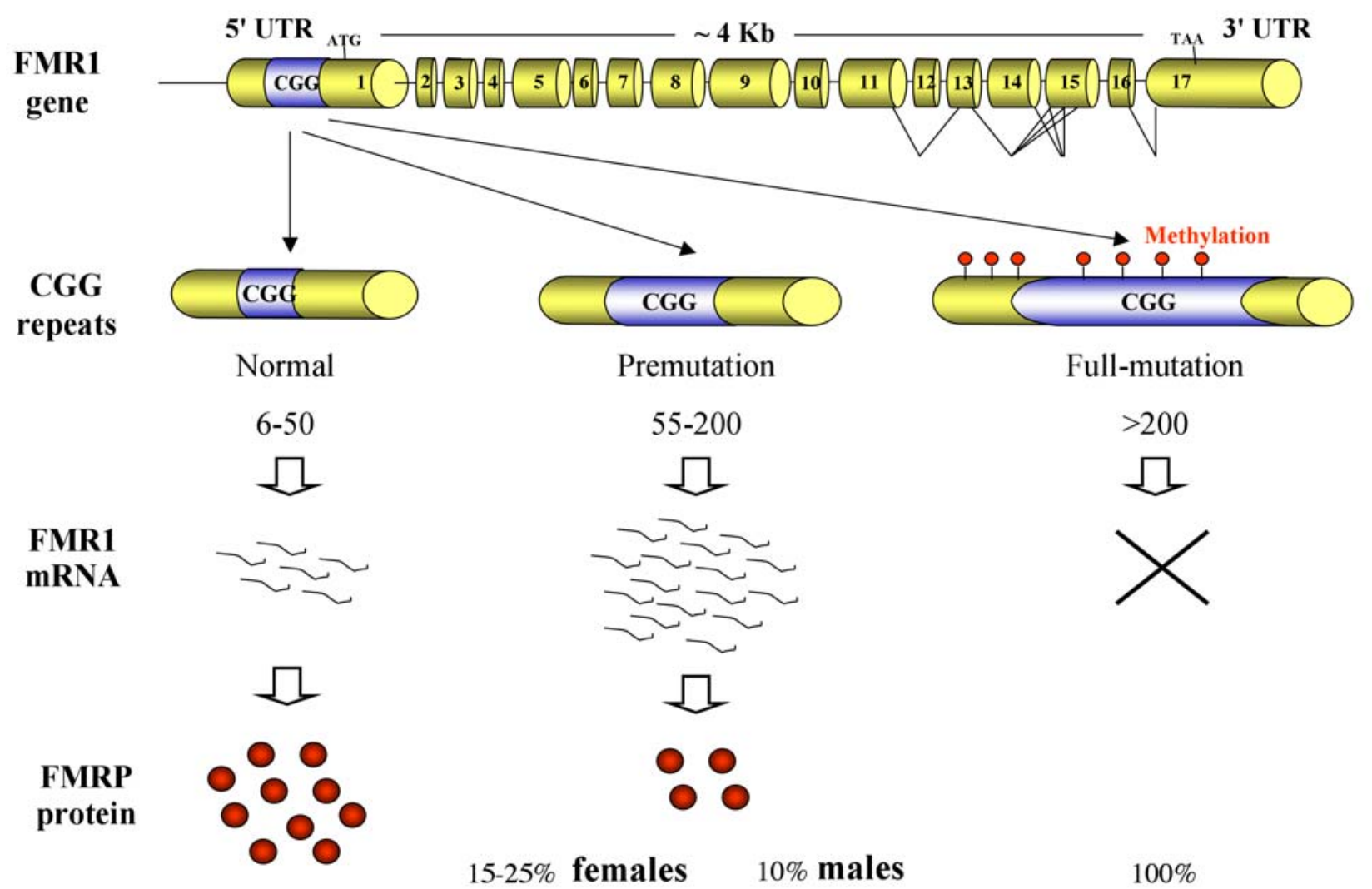

Phenotype

\author{
Premature Ovarian \\ Tremor/Ataxia \\ Failure (POF) Syndrome (FXTAS)
}

\title{
Fragile X \\ Syndrome (FXS)
}

Figure 1. Structure of FMR1 gene. FMR1 gene has 17 exons that can undergo alternative splicing in the 3' region of the gene. The gene presents, in the 5'UTR a CGG triplet expansion. According to the number of expansions, the cell has an FMR1 mRNA level leading to different FMRP protein concentration. According to FMRP protein concentration and number of triplets, there are three possibilities, a normal individual, premutated individual who will develop with FXTAS or POF syndrome, a full mutated individual who will develop Fragile X Syndrome.

on the RNA binding domains found in FMRP, because they will determine the way FMRP binds its RNA target. General principles of RNA recognition by proteins are apparent in consensus RNA recognition motifs.

The RGG box is an RNA binding domain consisting of RGG (Arg-Gly-Gly) repeats first identified in the C-terminus of hnRNP U (Kiledjian and Dreyfuss, 1992), and also present in other hnRNP proteins, several nucleolar proteins involved in RNA metabolism and some viral proteins (Zhang and Grosse, 1997; Sandri-Goldin, 1998). So far, it has been reported that the RGG box has evolved as an interaction motif to strengthen contacts in RNA-protein complexes (Lengyel et al., 2002) and is considered to have an accessory role in binding the RNA. This has been demonstrated for several RNA-binding proteins such as nucleolin (Ghisolfi et al., 1992; Fouraux et al. 2002), fibrillarin (Lapeyre et al., 1990), GAR1 in yeast (Bagni and Lapeyre, 1998) and NSR 1 (Lee et al., 1991). Moreover, in hnRNP A2, RGG repeats are critical for the cellular localization of the protein (Nichols et al., 2000).

The $\mathrm{K}$ homology $(\mathrm{KH})$ module, an evolutionarily conserved sequence motif that has been originally identified as three repeats in the human hnRNP K protein (Siomi et al., 1993; for a review see Adinolfi et al., 1999b), is present in a wide variety of quite diverse proteins from bacteria to human, indicating an early origin in evolution. The motif expands around a conserved VIGxxGxxI core sequence (where $x$ is any amino acid, with a preference for positive residues). In the aligned sequences, there are no absolutely conserved residues (Gibson et al., 1993; Musco et al., 1996). A preference for positively charged residues on and between the proposed helices suggests a possible surface of interaction with nucleic acids. Accumulating evidence shows that $\mathrm{KH}$-containing domains binds preferentially to specific RNAs (Gibson et al., 1993; Lewis et al., 2000). However, $\mathrm{KH}$ domains can also mediate binding to DNA (Duncan et al., 1994; Michelotti et al., 1996).

In addition to the $\mathrm{KH}$ domains and RGG box, the Nterminal domain of FMRP contains a significant RNA binding activity (Adinolfi et al., 1999a), it does not exhibit homology to any known RNA binding motif, however, it has been recently shown an homology with proteins belonging to the "Royal Family" (Maurer-Stroh et al., 2003). Further, it is not yet clear whether all RNA-binding motifs 


\section{FMR1 gene}

\section{5' UTR}

3' UTR
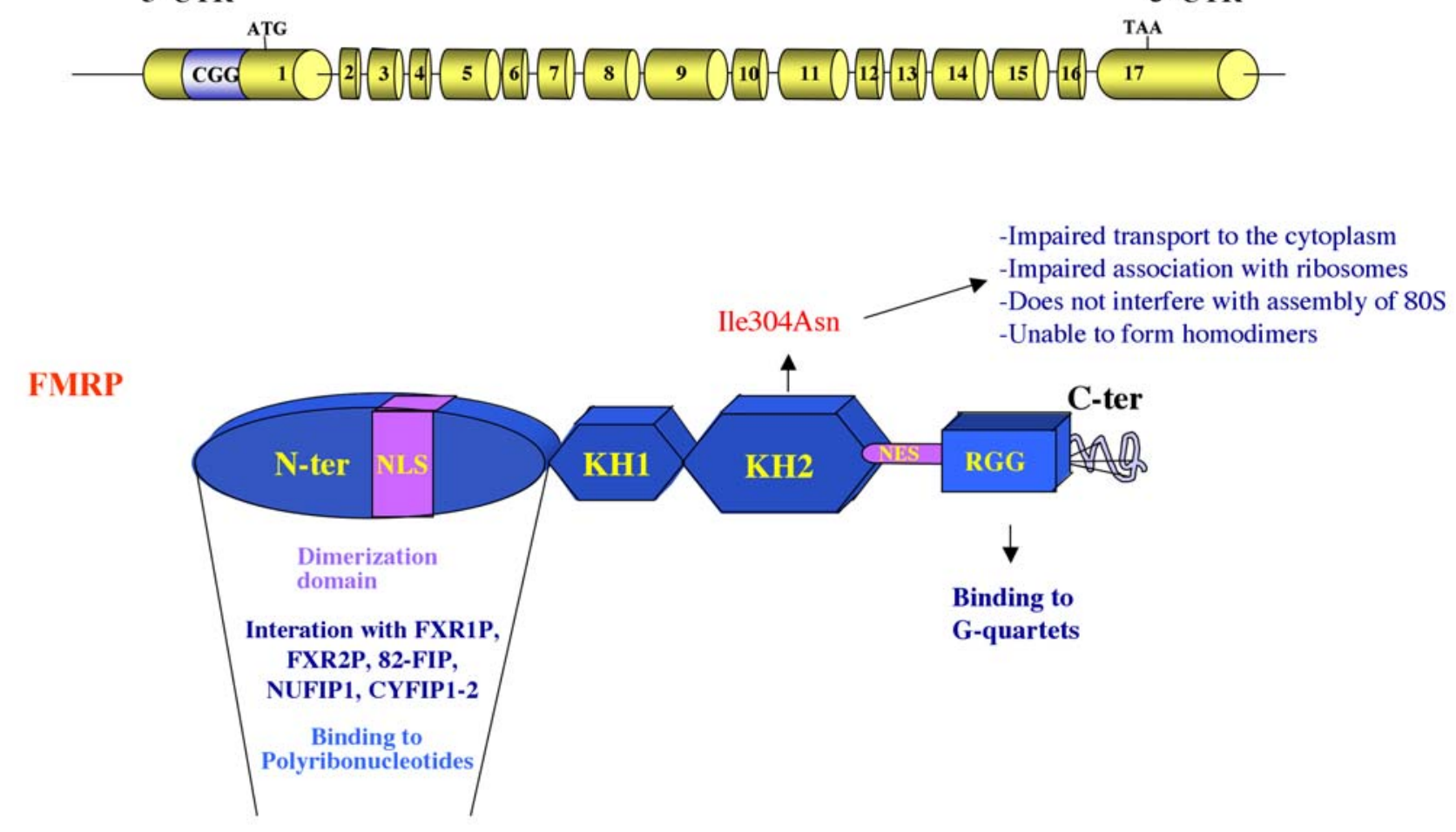

Figure 2. Structural and functional domains of FMRP. The protein presents four RNA binding domains, N-terminus, KH1, KH2, RGG box. A functional nuclear localization and export signals are also present. Each protein domain has also been shown to assolve one or more functions like interaction with RNAs and other proteins.

present in FMRP collaborate to bind to one RNA, or whether they can simultaneously accommodate several RNAs. Finally, the RNA binding motifs may also serve other roles. Interestingly, an Ile304-Asn missense mutation was identified in the second $\mathrm{KH}$ module of FMR1 in a particularly severe Fragile X patient (DeBoulle et al., 1993; Figure 2). The mutation lies at the core of the hydrophobic RNA binding pocket of the $\mathrm{KH}$ domain (Lewis et al. 2000) and partially alters the RNA binding activity of FMRP (Siomi et al., 1994; Feng et al., 1997a; Brown et al., 1998). Significantly, the mutated FMRP is unable to form homodimers (Feng et al., 1997b), to inhibit the translation of various mRNA in vitro and to inhibit the formation of the initiation complex 80S (Laggerbauer et al., 2001; Li et al., 2001). Finally, FMRP lle304-Asn missense mutation does not shuttle rapidly between the nucleus and the cytoplasm (Tamanini et al., 1999).

In summary, FMRP shares a domain structure typical of hnRNP proteins, binds mRNA in vitro, and association with various RNAs has been demonstrated. The real targets of FMRP binding, however, remain elusive. To elucidate these targets, animal models are necessary.

\section{The biological model systems to study the human syndrome}

The FMRP protein family is highly conserved in evolution and at least one FMR1-homologous protein has been characterised in Xenopus, Drosophila, chicken, mouse and human (Verkerk et al., 1991; Price et al., 1996; Wan et al., 2000). No FMR1 gene is present in yeast and $C$. elegans (Shtang et al. 1999). FMR1, FXR1 and FXR2 genes have all been identified in several species, while the Drosophila genome encodes only one member of the family. Major insights into the function of the FXR family proteins have been obtained by studies on mouse and Drosophila.

FMR 1 is highly conserved between human and mouse with a nucleotide and amino acid identity of $95 \%$ and $97 \%$ respectively (Ashley et al., 1993). The expression pattern of murine FMR1 is similar to its human counterpart in both tissue specificity and timing of expression (Hinds et al., 1993). The FMR1 knockout mouse was generated by homologous recombination disrupting exon 5 . This murine model for the fragile $X$ syndrome lacks normal FMRP protein and shows macroorchidism, deficit in spatial learning ability, hyperactivity (Bakker et al., 1994), and dendritic spine abnormalities (Comery et al., 1997; Irwin et al., 2001; Nimchinsky et al. 2001). With these features, 


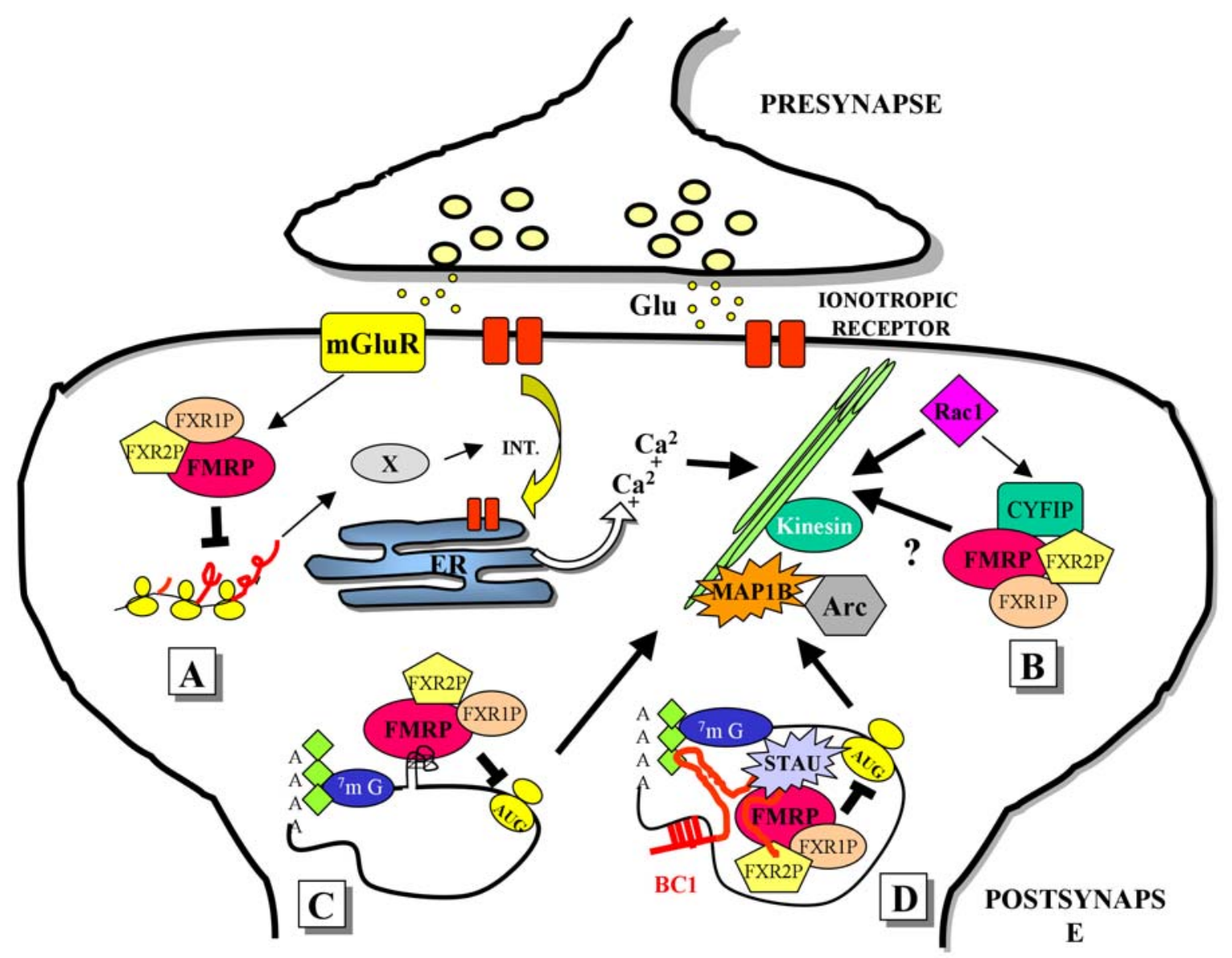

Figure 3. FMRP working model at synapses. The FMRP-ribonucleoparticles are probably transported to synapses via microtubules and motor proteins. At synapses, protein synthesis occurs according to the different cellular stimuli leading to an independent response of the single synapse influencing synaptic plasticity. (A) The stimulation of mGluRs enhances the FMRP synthesis, which act as a negative regulator of translation of proteins (X) involved in ionotropic receptor internalization during the long-term depression (LTD) in hippocampus. This process could bring to an increase of mGluR-dependent LTD that could effect on the lengthening of dendritic spines via a local increase of calcium from internal stores. (B) Cytoskeleton and synaptic remodelling occurs also via the Rac1 pathway that is modulated by the action of CYFIP-FMRP complex. To inhibit the translation of mRNA encoding key synaptic proteins, FMRP can probably bind mRNAs via the G-quartet present on the selected mRNAs (C) or via adaptor/bridge molecules like BC1/BC200 (D).

the FMR1 mouse is at least phenotipically a fair model for the Fragile $X$ syndrome. Molecularly, the ideal model is a knock in mouse with a CGG expansion higher than 100 that, due to technical reasons is difficult to generate. Only recently instability of CGG repeats has been observed in transgenic mice but in this case the endogenous gene has not been replaced (Baskaran et al., 2002). Underlining the poor performance in memory and learning, the FMR1 mouse shows impaired synaptic plasticity in the brain centres responsible for learning, in particular reduced longterm potentiation (LTP) in the cortex and enhanced mGluRdependent long-term depression (LTD) in the hippocampus (Huber et al., 2002; Li et al., 2002), both which further show changes in synaptic plasticity processes. Thus, this mouse model is highly suitable for a molecular analysis of the target mRNAs/RNAs and of interacting proteins, as has been presented by several groups (see below). Hopefully, this analysis will lead in the future to a better understanding of the human disease.
Recently, a FMR1 gene homologue has been identified and characterised in Drosophila and named dfxr (Wan et al., 2000). Other than in mammals, the fly has only one gene encoding an FMRP-related gene. Either, dfxr fulfils the role of all three mammalian counterparts, or mammals have three related pathways each of which needs one specialised $f x r$ family member. Interestingly, $d f x r$ gene is most similar to FXR2, and both $\mathrm{dFXR}$ and mouse FXR2P have a role in the circadian clock (Dockendorff et al., 2002; Morales et al., 2002; Bontekoe et al., 2002). Thus, this might be the function from which the FMRP family evolved.

$\mathrm{dFXR}$ is expressed at high levels in the central nervous system and in the muscle where it is localised to the cytoplasm. The expression pattern of $\mathrm{dFXR}$ during Drosophila embryogenesis reflects a combination of the tissue distributions of FMR 1 and the FXR proteins observed in mouse and human embryos (Wan et al., 2000) and a splice variant is expressed differentially during embryogenesis (Schenck et al., 2002). Overexpression of 


\begin{tabular}{|c|c|c|c|c|}
\hline $\begin{array}{l}\text { FMRP } \\
\text { interactor }\end{array}$ & Cellular localization & $\begin{array}{l}\text { Binding to other } \\
\text { FMRP interactors }\end{array}$ & $\begin{array}{l}\text { RNA binding } \\
\text { activity }\end{array}$ & Isolation method \\
\hline FXR1P & nucleus and cytoplasm & FXR2P, CYFIP2 & + & yeast two-hybrid system (Zhang et al., 1995) \\
\hline FXR2P & nucleus and cytoplasm & CYFIP2 & + & yeast two-hybrid system (Zhang et al., 1995) \\
\hline NUFIP1 & nucleus & / & + & yeast two-hybrid system (Bardoni et al., 1999) \\
\hline CYFIP1 & cytoplasm & 1 & + & yeast two-hybrid system (Schenck et al., 2000) \\
\hline CYFIP2 & cytoplasm & FXR1P, FXR2P & + & high sequence homology with CYFIP1 (Schenck et al. 2000) \\
\hline 82-FIP & nucleus and cytoplasm & / & + & yeast two-hybrid system (Bardoni et al., 2003) \\
\hline Nucleolin & nucleus & / & + & Co-immunoprecipitation (Ceman et al., 1999) \\
\hline YB1/p50 & nucleus & / & + & Co-immunoprecipitation (Ceman et al., 2000) \\
\hline Staufen & cytoplasm & Pur- $\alpha$ & + & Co-immunoprecipitation (Ohashi et al., 2002) \\
\hline Pur- $\alpha$ & cytoplasm & $\begin{array}{l}\text { Myosin Va mStaufen } \\
\text { FXR1P-FXR2P }\end{array}$ & + & Co-immunoprecipitation (Ohashi et al., 2002) \\
\hline Myosin Va & cytoplasm & Pur- $\alpha$ & + & Co-immunoprecipitation (Ohashi et al., 2002) \\
\hline
\end{tabular}

$d f x r$ leads to cell death by apoptosis (Wan et al., 2000). $d f x r$ null flies display enlarged synaptic terminals, whereas neuronal overexpression results in fewer and larger synaptic buttons (Zhang et al., 2001). Synaptic structural defects are accompanied by altered neurotransmission. The synaptic dFXR phenotypes mimic defects observed in mutants with altered levels of Futsch, a microtubuleassociated protein with homology to mammalian MAP1B (Hummel et al., 2000; Roos et al., 2000). Interestingly, it was demonstrated that dFXR associates with futsch mRNA and negatively regulates Futsch expression. Moreover, a $d f x r / f u t s c h$ double mutant restores the dfxr synaptic structural and functional defects in the eye and neuromuscular junctions, suggesting that $d F X R$ is acting as a translational repressor of Futsch to regulate microtubule-dependent synaptic growth and function (Zhang et al., 2001).

Finally, Schenck et al. presented data suggesting that the Drosophila homolog CYFIP could be the missing link between FMRP activity and cytoskeleton remodelling at synapses (see below) (Schenck et al., 2003). In summary, studies of the two animal models have significantly advanced our understanding of the molecular basis underlying the observed macroscopic and microscopic defects in the Fragile $X$ patients.

\section{FMRP-interacting proteins}

Many, if not most, proteins do not function alone but as a complex with other biological macromolecules, proteins or nucleic acid. Knowledge of the identity and contribution of interacting proteins is therefore essential to understand the function of FMRP. Using two-hybrid assay in yeast and the N-terminal portion of FMRP as a bait, Mandel, Bardoni and colleagues have isolated and characterised a significant number of putative FMRP-interacting proteins (for a review Bardoni and Mandel, 2002).

Among them, FXR1P and FXR2P have already before been shown to interact with FMRP in the nucleus and in the cytoplasm (Zhang et al., 1995). These proteins interact with the N-terminal portion of FMRP that indeed is a homodimerisation/heterodimerisation domain (Siomi et al., 1996; Adinolfi et al., 2003. Figure 2).

Moreover, the two-hybrid screens identified several murine and human proteins capable of interacting with
FMRP, which have been named for their sub-cellular localisation. The nuclear FMRP-interacting protein NUFIP1 is an RNA binding protein localised in the nucleus in a punctuate pattern, capable of nucleo-cytoplasmic shuttling. It does not interact with FXR1P and FXR2P, and only recently, via a multiple sequence alignment, Maurer-Stroh et al. found that NUFIP1 is a homologue of Saccharomyces cerevisiae Rsa1p, a protein involved in a nucleoplasmic assembly step of $60 \mathrm{~S}$ ribosomal subunits (Bardoni and Mandel, 2002; Maurer-Stroh et al., 2003).

The cytoplasmic FMRP-interacting proteins CYFIP1 and 2 are highly homologous to each other. CYFIP2 interacts with all the FXR family members, while CYFIP1 is specific for FMRP. CYFIP1 and 2 are localised at synapses (Schenk et al., 2001) and CYFIP1 was previously identified as an interactor of the small GTPases Rac1 (Kobayashi et al., 1998). As already mentioned, very recent data using the Drosophila system have linked $d f x r$ to the Rho-GTPase pathway and synapsis formation (Schenck et al., 2003) (Figure 3B).

The 82 kDa FMRP-interacting protein, 82-FIP, appears to be localised both in the nucleus and cytoplasm. It shows no homology to proteins of known function or to any known functional domain and, similarly to NUFIP1 and CYFIP1, interacts with FMRP but not with FXR1P and FXR2P. The protein is found in most neurons and is cell-cycle dependent in culture cells (Bardoni et al., 2003).

Immunoprecipitation experiments identified further FMRP-interacting proteins, including nucleolin, YB1/p50, Pura, and Staufen (Ceman et al., 1999, 2000; Ohashi et al., 2002). Pur proteins and Staufen are implicated in regulation of mRNA transport and translation (Li et al., 2001; Kohrmann et al., 1999; Duchaine et al., 2002) via a possible interaction with a kinesin motor (Ohashi et al., 2000). Consistent with a synaptic function, both Pur proteins and Staufen are associated in a complex containing the small dendritic non messenger RNA BC1 (Ohashi et al., 2002; Mallardo et al., 2003).

Further, Willemsen and colleagues have shown that FMRP moves in neurites of PC12 cells as a particle in a microtubule dependent manner (De Diego Otero et al., 2002). Together, these data strongly suggest a role in dendritic/axonal transport of the respective FMRP complex(es). 
The functional significance of most of these interactions, summarized in Table 1, remains to be firmly established. The upcoming picture, however, suggests that FMRP may function as a shuttle protein between the nucleus and the cytoplasm that interacts with different protein and RNA components mediating processes of DNA regulation, RNA transport and translation. Thus, it can be conceived that FMRP associates with an RNA starting from its transcription, during transport, and up to its translation, possibly fine-tuning several of these steps. Interestingly, even if FMRP is not present, some dendritic mRNAs that have been shown to bind to FMRP, including Arc and $\alpha$ CaMKII, are apparently normally localised in FMR1 KO mice (Steward et al., 1998). We should expect to find different ribonucleocomplexes containing FMRP, FXR1P and FXR2P that can be dynamically changed according to the various steps of FMRP function and the physiological needs of the cell. Since FMRP in particular is not an essential protein, we expect it to play a role only for a subset of the neuronal mRNPs and to fine-tune aspects of neuronal function rather than being a housekeeping gene that is necessary for expression of every mRNA.

\section{FMRP and its targets mRNAs}

Towards unravelling the pathogenesis of the Fragile $X$ syndrome, it is important to elucidate the mRNA targets of FMRP in healthy cells. Several approaches have been successfully used to isolate FMRP target RNAs. These studies have identified a series of putative in vivo ligands and one structural RNA motif that mediates FMRP binding.

The first approach made use of precipitated RNA from human brain extracts using biotinylated-FMRP affinity resins. Few RNAs were identified and did not point to a certain cellular function. Most remarkable is the identification of the FMR1 mRNA as it suggests that FMRP binds to its own messenger (Sung et al., 2000). Further, this study identified several repetitive elements, the significance of which is not clear. In this case, the authors claim that only the $\mathrm{KH} 2$ domain is required for the binding. Warren and colleagues had previously shown that FMRP binds in vitro its own mRNA as well as to MBP mRNA (Brown et al., 1998). Recently, the same authors (Brown et al., 2001) have used immunoprecipitation from mouse brain and a microarray technique to identify co-precipitating RNAs. 432 mRNAs have been identified that are associated with FMRP, and $5 \%$ of which encode proteins involved in synaptic function, where the most pronounced defect in Fragile $X$ is located. Further analysis using lymphoblastoid cells from Fragile $X$ patients compared to healthy controls showed that 251 human mRNAs are both up- and downregulated at the translational level. For three mRNAs, the change in translational activity was verified by checking the distribution on a polysome gradient, even though in this case no quantification has been reported. Finally, the 80 mRNAs that were most significantly precipitated with FMRP were compared with the up- or down-regulated mRNAs. 11 mRNAs are found in both sets, suggesting a direct regulation by FMRP. It should be noted that lymphoblastoids are non-neuronal cells and therefore, important co-factors of FMRP regulation may be missing in these cells. Among the $11 \mathrm{mRNAs}$, there is the MAP1B mRNA that has also been found to be translationally repressed using Drosophila mutants and FMR1 KO mice (Zhang et al., 2001; Zalfa et al., 2003).

In another microarray approach, Cavallaro and colleagues analysed how the presence or absence of FMRP influences the abundance of mRNAs, usually assumed to reflect strength of transcription. They compared mRNA levels from control wildtype and FMR1 KO mice with high-density cDNA microarrays containing 8731 cDNA clones (D'Agata et al., 2002). A change of more than twofold was observed for the mRNA levels of 73 genes. 41 of these did not have homology to any known gene, while the remaining 32 genes have similarity to known genes and could be grouped into four different classes: signal transduction, metabolism, structural proteins and nucleic acid synthesis and modification. Among the known mRNAs that showed more than 10 fold change, they found Ubiquitin specific protease 7 and Microtubule-associated protein 2 (MAP2). None of these mRNAs was common to the ones found in the previous work from Warren and colleagues (Brown et al., 2001) even if they belong to the same functional groups.

Darnell and collaborators (Darnell et al., 2001) have shown, using in vitro selection of random RNA sequences (SELEX) that the RGG box binds a class of mRNAs with a characteristic tertiary structure, namely the G-quartets. Mapping of an FMRP-binding element on the FMR1 mRNA had independently demonstrated that FMRP binds to $G$ quartets (Schaeffer et al., 2001). This finding introduces a new vision in terms of RNA-protein interaction because the RGG box has been considered to be a non-specific RNA binding domain that unfolds RNA secondary structure and is unable of sequence-specific RNA binding (for a general reading Dandekar, 2002). 31 candidate mRNAs containing a $\mathrm{G}$ quartet motif were identified in the database. Twelve of these were assayed for FMRP binding and six RNAs bound to FMRP with considerable affinities having a $\mathrm{K}_{\mathrm{d}}$ ranging from $75 \mathrm{nM}$ to $467 \mathrm{nM}$. All of them are associated with synaptic function and included MAP1B mRNA. The other 6 did not interact with FMRP.

In collaboration with Warren's lab, the authors then analysed the distribution of these mRNAs on polysome gradients to gauge the efficiency with which they are translated. This joined work thus yielded a list of 6 RNA targets containing G-quartets that directly bind to FMRP and change their translational efficiency in Fragile $X$ cell lines (Darnell et al., 2001, Figure 3C)

The Eberwine and Greenough laboratories describe, using the sophisticated technique of Antibody Positioned RNA Amplification technique, APRA, around 80 new molecules that are associated to FMRP (Miyashiro et al., 2003). They found RNAs encoding proteins involved in multiple functional pathways, such as receptors, signalling, cell structure, secretory pathways, and gene expression. The mRNA targets identified did not overlap with the previous study (Brown et al., 2001) probably due to different microarrays used and/or due to different starting material (cultured neurons, whole brain) in the two studies. Finally, only a minority of the RNAs that bind to FMRP (23\%) contain a $\mathrm{G}$ quartet, suggesting that this motif is not the 
sole determinant of FMRP binding. These varying data clearly show on one side that it is extremely difficult to obtain an absolute result using the chip/array technology, and on the other side provide a broad range of putative molecules that can be further studied using a more functional approach.

Finally, we have shown that FMRP binds strongly to the small non-messenger cytoplasmic RNA $B C 1$, and $B C 1$ simultaneously associates with some mRNAs regulated by FMRP, strongly suggesting that $B C 1$ RNA recruites FMRP to the targeted mRNAs, thereby determining the specificity of FMRP action (Zalfa et al., 2003). To support this hypothesis, we searched for regions of complementarity between $B C 1$ and the regulated mRNAs. We found that $B C 1 \mathrm{RNA}$ is predicted to basepair to MAP1B, $\alpha$-CaMKII and Arc mRNAs (Figure 3D). Interestingly, the sequence complementarity is found at the base of the longer stem-loop, according to a stable predicted secondary structure of $B C 1$ RNA (Rozhdestvenski et al., 2001). Thus, $B C 1$ is an important factor in FMRP-mediated translational repression. Consistently, it has been recently shown that $B C 1$ participates in translational repression in vitro by inhibiting the formation of the $48 \mathrm{~S}$ preinitiation complex (Wang et al., 2002). Further substantiating the role in translational control, $B C 1$ has also been shown to associate with poly $(A)$ binding protein and elF4A (Muddashetty et al., 2002). Thus, BC1 RNA acts as a bridge between FMRP and specific target mRNAs forming the translational inhibition complex.

In this sense, $B C 1$ acts similarly to the micro RNAs (miRNAs). Although much smaller (22 nt on average), miRNAs form imperfect base-pairings with their target RNAs and inhibit, in an yet poorly understand manner, translation of these RNAs. Up to now, several hundred miRNAs have been identified in C.elegans, Drosophila and mammals, but the corresponding target mRNAs have proven difficult to identify, not least because the base pairing interactions are short and imperfect. Only recently target genes have been identified in mammals (Kawasaki and Taira, 2003). Similar difficulties are to be expected when looking for the additional $B C 1$ targets. And the analogies may even stretch further: lately, dFXR has been shown to associate with microRNAs as well as to the exonuclease DICER, a key enzyme in the biogenesis of miRNPs (Caudy et al., 2002; Ishizuka et al., 2002). Therefore, members of the FXR family appear to be part of the functional miRNP complexes, and it is conceivable that they actually provide the translational silencing activity of the miRNP complex.

It is possible that various mRNAs interact with FMRP according to their sequence signals, for example, G-quartet structure binds to the RGG box of FMRP (Darnell et al., 2001), while other mRNAs bind to different RNA binding domains of FMRP, or associate via BC1 RNA. Possibly, the individual binding mode may also determine whether the FMRP-mRNA complex participates in nuclear processes, nucleo-cytoplasmic shuttling, dendritic/axonal mRNA transport, or translational control (see also above).

It becomes clear that, thanks to different experimental approaches, we now have a wide collection of candidate targets for the Fragile $X$ protein. This will be the starting point for developing functional studies and pharmacological treatments.

\section{FMRP as a new regulator of translation}

Based on its association to polysomes and mRNPs, it has been hypothesised that FMRP has a role in translational regulation of gene expression in neurons and probably in testis. Two different groups have indeed shown that FMRP functions in vitro as an unspecific repressor of translation (Li et al., 2001; Laggerbauer et al., 2001) and lately the same result has been extended to cell culture using cotransfection experiments (Mazroui et al., 2002). To define how translation is inhibited, it is extremely important to define whether FMRP co-associates on a polysomal gradient with the smaller complexes including mRNPs, ribosomes, and ribosomal subunits (ribonucleoparticle or mRNP fraction), or with the larger complexes containing predominantly actively translating ribosomes (polysome fraction). The first would indicate a role as repressor in translational initiation, the latter in translational elongation and/or termination.

Since 1996, a long debate has arisen concerning the FMRP distribution/co-localization with the ribosomes/ polysomes. At the beginning, Kandjian and colleagues (Khandjian et al., 1996) described, using non-denaturing detergents in extract preparation (0.5\% NP-40), the association of FMRP to actively translating polyribosomes. In the same year, Dreyfuss and colleagues (Siomi et al., 1996) published that FMRP is associated to ribonucleoparticles, in particular to the 40S-60S and $80 S$ fractions. These last results were obtained using a different protocol that did not include detergent. Since then, several laboratories have tried to detect the association of FMRP with the polysomes-mRNPs. Interestingly, Warren and colleagues showed that FMRP is equally distributed between polysomes and mRNPs using conditions similar to the ones used by Kandjian and colleagues ( $0.3 \%$ NP40: Feng et al., 1997b; Brown et al., 2001). Finally, Siomi and collaborators in Drosophila have shown that $\mathrm{dFXR}$ is associated to the $80 \mathrm{~S}$ and ribonucleoproteins when the cytoplasmic extracts are treated with a similar detergent (0.5\% Triton: Ishizuka et al., 2002). Given the above background, we wished to characterize the distribution of FMRP on a polysomal gradient using a new specific antibody for FMRP against the C-terminus of the protein. Using different chemical conditions (in the presence or absence of detergents like triton $0.2-0.5 \%$ ), our data clearly point out that FMRP is part of the ribonucleoprotein fraction, in agreement with its role as repressor of translational initiation (Zalfa et al., 2003, and unpublished observations). Indeed, using rabbit reticulolcyte extracts it was shown that FMRP inhibits the assembly of 805 ribosomes on the target RNAs (Laggerbauer et al., 2001).

Thus, it is still disputed how FMRP inhibits translation. The picture of how FMRP selects its target mRNAs, in contrast, starts to become clearer.

\section{FMRP involvment in synaptic plasticity}

\section{Spine dysmorphogenesis: cause or effects?}

Dysmorphogenesis of the spines associated with mental retardation was initially described by Purpura (Purpura, 
1974). The common characteristics found within the Fragile $X$ patients by Rudelli and Greenough's labs are longer and thinner spines compared to control individuals (Rudelli et al., 1985; Hinton et al., 1991; Irwin et al., 2001). Considering that this investigation has been performed on post-mortem patients, it becomes clear that the number of individuals analysed is limited. A total of 6 human brains have been so far studied and the detailed familiar histories are not known for each patient implying that other brain pathologies can not be excluded. Nevertheless the three independent studies showed long and thin prominent spine heads resembling immature spine-like structures called filipodia (Rudelli et al., 1985).

Impaired spine morphology in the barrel region of somatosensory cortex as well as in hippocampal neurons has also been reported in mice (Comery et al., 1997; Braun and Segal, 2000; Nimchinsky et al., 2001). While in the animal model this phenotype/morphology seems to be transitory, in human this morphology persists as it is described in the post-mortem patients (Greenough et al., 2001).

In the mouse model, FMRP has been shown to localize to spines (Feng et al., 1997a) and to be regulated in an activity-dependent manner (its levels can increase after barrel cortex stimulation and rearing mice in complex environments) both in cortex and hippocampus, two structures important in learning and memory (Irwin et al., 2000). It has been shown that FMR1 mRNA is present in synaptoneurosomes and the synaptic level of FMRP increases following administration of specific mGluRspecific agonists (Weiler et al., 1997). We have shown that FMRP regulates local mRNA translation that is considered to be a regulation step involved in long-term plasticity. Activity-dependent potentiation of synaptic transmission is expressed through multiple parallel mechanisms and requires new protein synthesis. Localised synaptic protein synthesis is considered an important component of synaptic plasticity. In this way, neurons may translate new proteins exactly where they are needed to modify synapses in response to potentiating stimuli (for a review Steward and Schuman 2001). It has been shown that polyribosomes redistribute from dendritic shafts into spines with enlarged synapses during LTP (long-term depression) in developing rat hippocampal slides. Moreover, after stimulation the spines had enlarged synapses, which may serve to sustain the potential response (Ostroff et al., 2002). This indicates that stimulation of synapses coincides with an enlargement of the structure, which serves at least in part to accommodate local protein synthesis machinery. Thus, local protein synthesis is an important part of synaptic plasticity.

\section{Electrophysiological studies on the Fragile $X$ mouse model}

Synaptic plasticity, indeed the ability to change the synaptic structure is thought to be directly correlated to learning and memory, which are the major impairment in the Fragile $X$ patients. There are two major in vitro models for the study of synaptic plasticity: the electrophysiological long-term potentiation (LTP) and the long-term depression (LTD). A major contribution to both effects comes from the glutamergic receptor system. Its receptors fall into two general classes, the ionotropic and the metabotropic receptors. The ionotropic AMPA and NMDA receptors at glutamergic synapses are heteromeric complexes of homologous subunits (GluR1-4 for AMPA receptors and NR1, NR2A-D for NMDA receptors) that differentially combine to form various receptor subtypes (Hollmann and Heinemann, 1994). Metabotropic glutamate receptors (mGluR) are made of eight different members that can be subdivided into three groups on the basis of sequence homologies and their capacity to couple to specific enzyme systems. In the KO mouse for FMR1, the mGluRdependent LTD was found to be increased in hippocampal slides (Huber et al., 2002). This form of LTD depends on the postsynaptic protein synthesis and involves internalisation of AMPA and NMDA receptors (Synder et al., 2001; Figure 3A). Bear and collaborators suggest that FMRP may negatively regulate mRNAs encoding for proteins involved in mGluR dependent LTD affecting hippocampal LTD (Huber et al., 2002). According to this model, a link between FMRP, the glutamatergic system and synaptic plasticity could be the local increase of calcium from internal stores affecting at the end the lengthening of dendritic spines (Vanderklish and Edelman, 2002; Figure 3A).

Interestingly, it has been shown that GluR1 is downregulated in the cortex in the FMR1 KO mice accompanied by a reduction in NMDA-AMPA mediated LTP, another process dependent on local protein synthesis (Li et al., 2002) while no effect has been observed on hippocampal LTP (Godfraind et al., 1996) . Although the GluR1 subunit of the AMPA receptor does not appear to be directly controlled by FMRP, the mRNA encoding for the alpha $\mathrm{Ca}^{++}$/ calmodulin-dependent protein kinase II it is regulated (Zalfa et al., 2003). AMPA receptors have been shown to be phosphorylated by several protein kinases including PKC, cAMP-dependent protein kinase (PKA) and CaMKII (Tan et al., 1994; Roche et al., 1996). In 2002 Poncer et al. have shown that expression of a recombinant constitutively active form of $\alpha$-CaMKII specifically potentiates AMPA- but not NMDA-mediated signal transmission in infected neurons, suggesting that the increased conductance seen in their system likely involves direct phosphorylation of GluR1 (Poncer et al., 2002). Furthermore, investigations of activity-dependent development of neurons within several regions of the nervous system have demonstrated the involvement of the ionotropic glutamate receptors, both NMDA and AMPA (Inglis et al., 2002; Song and Hugarin, 2002; Sala et al., 2003) in controlling dendrite morphogenesis.

Using the FMR1 KO mouse model, we have shown that translational repression in vivo by FMRP is strongest in the dendritic/synaptic fraction, where it regulates in particular specific dendritic mRNAs, including those encoding key synaptic proteins like Arc/Arg3.1, MAP1B and $\alpha$-CaMKII (Zalfa et al., 2003) (Figure 3D).

Finally, another link between spine morphology and FMRP activity was recently reported above by Schenck et al. Initially, Mandel and colleagues (Schenck et al., 2001) showed that one of the cytoplasmic interactors of FMRP, Cytoplasmic FMRP Interacting Protein 1 (CYFIP1) binds 
also to Rac1, a member of the Ras superfamily of GTPases (Kobayashi et al., 1998). The Ras family members regulate actin cytoskeleton and are implicated in dendritic modelling (Nakayama et al., 2000, Figure 3). We have shown, in collaboration with Mandel's group, that CYFIP1 is also present at synapses (Schenck et al., 2001). The role of $\mathrm{dFXR/FMRP}$ and Rac1 in cytoskeleton modelling of the synapses is conclusively demonstrated by elegant Drosophila studies by Schenck et al. (2003). They clearly show that $d C Y F I P$ mutant neurons exhibit impaired axonal pathfinding and growth and defects in motor axon terminals. Finally, they show that biochemical interactions between dCYFIP and dfxr or dRac1 are mutually exclusive and they establish that these molecules act in a common genetic pathway controlling the neuronal and synaptic morphology (Figure 3B).

\section{Undiscovered roles of FMRP}

Although FMRP by immunoistochemistry is localized in the cytoplasm, both a functional nuclear localization signal (NLS) and a nuclear export signal (NES) have been identified within FMRP, suggesting that FMRP might shuttle between the nucleus and cytoplasm (Eberhart et al., 1996). A small amount of FMRP has been revealed in the nucleus by both light and electron microscopy (Verheij et al., 1993; Eberhart et al., 1996; Feng et al., 1997a). Cells treated with Leptomycin B, which blocks mRNA export, partially retains FMRP and the FXRs in the nucleoplasm indicating that the nuclear export of these proteins is dependent on mRNA export. An even more striking nuclear retention is observed for the mutated FMRP containing the lle304Asn amino acid substitution in the second $\mathrm{KH}$ domain (Tamanini et al., 1999). Even if a domain similar to an NLS has been identified in exon 14, overexpressed FMRP lacking exon 14 can indeed enter the nucleus (Fridell et al., 1996; Bardoni et al., 1997). Interestingly, this exon is alternatively spliced, and certain FMRP isoforms are therefore excluded from the nucleus (Sittler et al., 1996). FMRP appears to serve a role in the nucleus that is independent from its role at the synapses, since it associates with a distinct set of proteins in the nucleus, including nucleolin, YB1, and NUFIP (Ceman et al., 1999; 2000, Bardoni et al., 2002). Interestingly, a core particle containing FMRP, FXR1P and FXR2P is both present in the nucleus and cytoplasm. The nuclear function, however, still awaits further studies.

So far, work on FMRP has greatly focused and advanced on the mental retardation aspect. Patients with the Fragile $X$ Syndrome, however, exhibit a series of physical characteristics that are very heterogeneous. They include macroorchidism (Turner et al., 1980), long face and large ears (Opitz et al., 1984; Hagerman et al., 1984a, 1984b). Of these, the macroorchidism is particularly striking and consistently observed. Furthermore, Fragile X patients often exhibit connective tissue disorders, including velvetlike skin, finger-joint hyperextensibility, recurrent otitis media, aortic root dilatation, and mitral valve prolapse (Loehr et al., 1986, Hagerman and Cronister, 1996). Finally, there are behavioural abnormalities, frequently including autistic features ranging from shyness, poor eye contact, and social anxiety in less affected individuals to hyperactivity, hand flapping, hand biting, and perserverative speech in the severely affected (Merenstein et al., 1996), as well as seizures and EEG findings consistent with epilepsy (Musumeci et al., 1999, Sabaratnam et al., 2001). How and why lack of FMRP causes all these phenotypes is completely unknown. An intriguing idea is that modifier genes, common to other pathologies (heart or connective pathologies) could also be playing a role in the Fragile $X$ Syndrome.

In this context, it is also interesting to note that until few years ago the premutation carriers were considered not affected, just recently, it has been reported that premutation carriers exibit a clinical phenotype with particular and unique features: premature ovarian failure (POF) in females (16-24\% of total females with premutation alleles; Allingham-Hawkins et al., 1999) and a new neurological syndrome, recently identified in some males with premutations older than 50 years, called Fragile $X$ Tremor/Ataxia Syndrome (FXTAS), involving progressive action tremor with ataxia, cognitive decline and global reduction of brain volume (Hagerman et al., 2001). Both POF and FXTAS are absent in Fragile $X$ patients, therefore these phenotypes are considered unique to the premutation (Allingham-Hawkins et al., 1999) (Figure 1).

Some patients with FXTAS show also eosinophilic and ubiquitin-positive intranuclear inclusions in both neuronal and astrocytic nuclei of the cortex, cerebellum, brainstem and hippocampal formation (Greco et al., 2002). The origin of this inclusion is unknown, although elevated FMR1 mRNA levels in these premutation carriers may lead to the neuropathological changes (Greco et al., 2002). Interestingly, engineered mice with premutation alleles also show elevated FMR1 mRNA levels and ubiquitin-positive intranuclear inclusions in neuronal and glial cells (Willemsen et al., 2003).

\section{Future perspectives}

It is becoming clear that FMRP is involved in synaptic plasticity through at least two different ways, first the regulation of mRNA transport and translation, second the response to glutamate receptor mediated signalling. FMRP contains four different RNA binding domains that could in part cooperate and/or select a subpopulation of RNA according to the cellular need (nuclear function, transport from the nucleus, delivery to the synapses and translational regulation in the cell body as well as at synapses). While mRNA transport and translation seems to be not only limited to dendrites (Giuditta et al., 2002) from recent studies in Drosophila the function of FMRP in axons becomes more intriguing.

On one side, the future goal is now to understand how the different mechanisms reported as a scheme in Figure 3 can be linked one to the other to allow FMRP function in the cell. Deciphering how FMRP works will help to unravel the molecular and cellular bases of many neurological disorders as well as to gain insight into basic brain functioning.

On the other side, it is important to find a therapeutical strategy for the syndrome, since transcriptional silencing due to hypermethylation is responsible for the FMRP defect, 
it is conceivable that FMR1 promoter can be reactivated. Neri and collaborators have shown promising preliminary results in this direction (Chiurazzi et al., 1998).

\section{Acknowledgements}

We are extremely grateful to Tilmann Achsel for intensive discussions and critical reading of the manuscript. We thank Barbara Bardoni and Annalisa Pastore for suggestions on the manuscript and help during the course of our work on the Fragile $X$ Syndrome. Research in our laboratory is supported by grants from FRAXA Foundation (USA), Human Frontier Science Programm (HFSP), Italian Telethon Foundation.

\section{References}

Abitbol, M., Menini, C., Delezoide, A.L., Rhyner, T., Vekemans, M., and Mallet, J. 1993. Nucleus basalis magnocellularis and hippocampus are the major sites of FMR-1 expression in the human fetal brain. Nat. Genet. 4:147-153.

Adinolfi, S., Bagni, C., Musco, G., Gibson, T., Mazzarella, L., and Pastore, A. 1999a. Dissecting FMR1, the protein responsible for fragile $X$ syndrome, in its structural and functional domains. RNA 9:1248-1258.

Adinolfi, S., Bagni, C., Castiglione Morelli, M.A., Fraternali, F., Musco, G., and Pastore, A. 1999b. Novel RNA-binding motif: the KH module. Biopolymers 51:153-164.

Adinolfi, S., Ramos, A., Martin, S.R., Dal Piaz, F., Pucci, P., Bardoni, B., Madel, J.L, and Pastore, A. 2003. The NTerminus of the Fragile $X$ Mental Retardation Protein contains a novel domain involved in dimerization and RNA-binding. Biochemistry. 42: 10437-10444.

Allingham-Hawkins, D.J., Babul-Hirji, R., Chitayat, D., Holden, J.J., Yang, K.T., Lee, C., Hudson, R., Gorwill, H., Nolin, S.L., Glicksman, A., Jenkins, E.C., Brown, W.T., Howard-Peebles, P.N., Becchi, C., Cummings, E., Fallon, L., Seitz, S., Black, S.H., Vianna-Morgante, A.M., Costa, S.S., Otto, P.A., Mingroni-Netto, R.C., Murray, A., Webb, J., Vieri, F., et al. 1999. Fragile X premutation is a significant risk factor for premature ovarian failure: the International Collaborative POF in Fragile $X$ studypreliminary data. Am. J. Med. Genet. 3:322-325.

Antar, L.N., and Bassell, G.J. 2003. Sunrise at the synapse: the FMRP mRNP shaping the synaptic interface. Neuron 37:555-558.

Ashley, C.T., Jr., Wilkinson, K.D., Reines, D., and Warren, S.T. 1993. FMR1 protein: conserved RNP family domains and selective RNA binding. Science 262:563-566.

Bagni, C., and Lapeyre, B. 1998. Gar1p binds to the small nucleolar RNAs snR10 and snR30 in vitro through a nontypical RNA binding element. J. Biol. Chem. 273:10868-10873.

Bakker, C.E., Verheij, C., Willemsen, R., Vanderhelm, R., Oerlemans, F., Vermey, M., Bygrave, A., Hoogeveen, A. T., Oostra, B. A., Reyniers, E., et al. 1994. FMR1 knockout mice: a model to study fragile $X$ mental retardation. Cell 78:23-33.

Bardoni, B., Sittler, A., Shen, Y., and Mandel, J.L. 1997. Analysis of domains affecting intracellular localization of the FMRP protein. Neurobiol. Dis. 4:329-336.
Bardoni, B., and Mandel, J.L. 2002. Advances in understanding of fragile $X$ pathogenesis and FMRP function, and in identification of $X$ linked mental retardation genes. Curr. Opin. Genet. Dev. 12:284-293.

Bardoni, B., Castets, M., Huot, M.E., Schenck, A., Adinolfi, S., Corbin, F., Pastore, A., Khandjian, E.W., and Mandel, J.L. 2003. 82-FIP, a novel FMRP (Fragile X Mental Retardation Protein) interacting protein, shows a cell cycle-dependent intracellular localization. Hum. Mol. Genet. 12:1689-1698.

Baskaran, S., Datta, S., Mandal, A., Gulati, N., Totey, S., Anand, R.R., Brahmachari, V. 2002. Instability of CGG repeats in transgenic mice. Genomics. 80:151-157.

Bontekoe, C.J., Mcllwain, K.L., Nieuwenhuizen, I.M., YuvaPaylor, L.A., Nellis, A., Willemsen, R., Fang, Z., Kirkpatrick, L., Bakker, C.E., McAninch, R., Cheng, N.C., Merriweather, M., Hoogeveen, A,T., Nelson, D., Paylor, R., and Oostra, B.A. 2002. Knockout mouse model for Fxr2: a model for mental retardation. Hum. Mol. Genet. $11: 487-498$.

Braun, K., and Segal, M. 2000. FMRP involvement in formation of synapses among cultured hippocampal neurons. Cereb. Cortex. 10:1045-1052.

Brown, V., Small, K., Lakkis, L., Feng, Y., Gunter, C., Wilkinson, K.D., and Warren, S.T. 1998. Purified recombinant Fmrp exhibits selective RNA binding as an intrinsic property of the fragile $X$ mental retardation protein. J. Biol. Chem. 273:15521-15527.

Brown, V., Jin P, Ceman, S., Darnell, J.C, O’Donnell, W.T., Tenenbaum, S.A., Jin, X., Feng, Y., Wilkinson, K.D., Keene, J.D., Darnell, R.B., Warren, S.T. 2001. Microarray identification of FMRP-associated brain mRNAs and altered mRNA translational profiles in fragile $X$ syndrome. Cell. 107:477-487.

Caudy, A.A., Myers, M., Hannon, G.J., and Hammond, S.M. 2002. Fragile X-related protein and VIG associate with the RNA interference machinery. Genes. Dev. 16:24912496.

Ceman, S., Brown, V., and Warren, S.T. 1999. Isolation of an FMRP-associated messenger ribonucleoprotein particle and identification of nucleolin and the fragile $X$ related proteins as components of the complex. Mol. Cell. Biol. 19:7925-7932.

Ceman, S., Nelson, R., and Warren, S.T. 2000. Identification of mouse YB1/p50 as a component of the FMRP-associated mRNP particle. Biochem Biophys Res Commun. 279:904-908.

Chelly, J., and Mandel, J.L. 2001. Monogenic causes of Xlinked mental retardation. Nat. Rev. Genet. 2:669-680.

Chiurazzi, P., Pomponi, M.G., Willemsen, R., Oostra, B.A., and Neri, G. 1998. In vitro reactivation of the FMR1 gene involved in fragile X syndrome. Hum. Mol. Genet. 7:109113.

Comery, T.A., Harris, J.B., Willems, P.J., Oostra, B.A., Irwin, S.A., Weiler, I.J., and Greenough, W.T. 1997. Abnormal dendritic spines in fragile $X$ knockout mice: maturation and pruning deficits. Proc. Natl. Acad. Sci. USA. 94:54015404.

D'Agata V, Warren ST, Zhao W, Torre ER, Alkon DL, Cavallaro S.2002. Gene expression profiles in a transgenic animal model of fragile $X$ syndrome. Neurobiol Dis. 3:211-8. 
Dandekar, T. 2002. RNA motifs and regulatory elements. $2^{\text {nd }}$ ed. Springer.

Darnell, J.C., Jensen, K.B., Jin, P., Brown, V., Warren, S.T., and Darnell, R.B. 2001. Fragile $X$ mental retardation protein targets $\mathrm{G}$ quartet mRNAs important for neuronal function. Cell. 107:489-499.

De Boulle, K., Verkerk, A.J., Reyniers, E., Vits, L., Hendrickx, J., Van Roy, B., Van den Bos, F., de Graaff, E., Oostra, B.A., and Willems, P.J. 1993. A point mutation in the FMR-1 gene associated with fragile $X$ mental retardation. Nat. Genet. 3:31-35.

De Diego Otero, Y., Severijnen, L.A., van Cappellen, G., Schrier, M., Oostra, B., and Willemsen, R. 2002. Transport of fragile $X$ mental retardation protein via granules in neurites of PC12 cells. Mol. Cell. Biol. 22:8332-8341.

Devys, D., Lutz, Y., Rouyer, N., Bellocq, J.P., and Mandel, J.L. 1993. The FMR-1 protein is cytoplasmic, most abundant in neurons and appears normal in carriers of a fragile X premutation. Nat. Genet. 4:335-340.

Dockendorff, T.C., Su, H.S., McBride, S.M., Yang, Z., Choi, C.H., Siwicki, K.K., Sehgal, A., and Jongens, T.A. 2002. Drosophila lacking dfmr1 activity show defects in circadian output and fail to maintain courtship interest. Neuron 34:973-984.

Duchaine, T.F., Hemraj, I., Furic, L., Deitinghoff, A., Kiebler, M.A., and DesGroseillers, L. 2002. Staufen2 isoforms localize to the somatodendritic domain of neurons and interact with different organelles. J. Cell. Sci. 115:32853295.

Duncan, R., Bazar, L., Michelotti, G., Tomonaga, T., Krutzsch, H., Avigan, M., and Levens, D. 1994. A sequence-specific, single-strand binding protein activates the far upstream element of c-myc and defines a new DNA-binding motif. Genes. Dev. 8:465-480.

Eberhart, D.E., Malter, H.E., Feng, Y., and Warren, S.T. 1996. The fragile $X$ mental retardation protein is a ribonucleoprotein containing both nuclear localization and nuclear export signals. Hum. Mol. Genet. 5:1083-1091.

Eichler, E.E., Richards, S., Gibbs, R.A., and Nelson, D.L. 1993. Fine structure of the human FMR1 gene. Hum. Mol. Genet. 2:1147-1153.

Feng, Y., Gutekunst, C.A., Eberhart, D.E., Yi, H., Warren, S.T., and Hersch, S.M. 1997a. Fragile X mental retardation protein: nucleocytoplasmic shuttling and association with somatodendritic ribosomes. J. Neurosci. 17:1539-1547.

Feng, Y., Absher, D., Eberhart, D.E., Brown, V., Malter, H.E., and Warren, S.T. 1997b. FMRP associates with polyribosomes as an mRNP and the $1304 \mathrm{~N}$ mutation of severe fragile $X$ syndrome abolishes this association. Mol. Cell 1:109-118.

Fouraux, M.A., Bouvet, P., Verkaart, S., van Venrooij, W.J., and Pruijn, G.J. 2002. Nucleolin associates with a subset of the human Ro ribonucleoprotein complexes. J. Mol. Biol. 320:475-488.

Fridell, R.A., Benson, R.E., Hua, J., Bogerd, H.P., Cullen, B.R. 1996. A nuclear role for the Fragile $X$ mental retardation protein. EMBO J. 15:5408-5414.

Gedeon, A.K., Baker, E., Robinson, H., Partington, M.W., Gross, B., Manca, A., Korn, B., Poustka, A., Yu, S., Sutherland, G.R., et al. 1992. Fragile X syndrome without
CCG amplification has an FMR1 deletion. Nat. Genet. 1:341-344.

Ghisolfi, L., Kharrat, A., Joseph, G., Amalric, F., and Erard, M. 1992. Concerted activities of the RNA recognition and the glycine-rich C-terminal domains of nucleolin are required for efficient complex formation with pre-ribosomal RNA. Eur. J. Biochem. 209:541-548.

Gibson, T.J., Thompson, J.D., and Heringa, J. 1993. The $\mathrm{KH}$ domain occurs in a diverse set of RNA-binding proteins that include the antiterminator NusA and is probably involved in binding to nucleic acid. FEBS Lett. 324:361-316.

Giuditta, A., Kaplan, B.B., van Minnen, J., Alvarez, J., and Koenig, E. 2002. Axonal and presynaptic protein synthesis: new insights into the biology of the neuron. Trends. Neurosci. 25:400-404.

Godfraind, J.M., Reyniers, E., De Boulle, K., D'Hooge, R., De Deyn, P.P., Bakker, C.E., Oostra, B.A., Kooy, R.F., and Willems, P.J. 1996. Long-term potentiation in the hippocampus of fragile $X$ knockout mice. Am. J. Med. Genet. 64:246-251.

Greco, C.M., Hagerman, R.J., Tassone, F., Chudley, A.E., Del Bigio, M.R., Jacquemont, S., Leehey, M., and Hagerman, P.J. 2002. Neuronal intranuclear inclusions in a new cerebellar tremor/ataxia syndrome among fragile X carriers. Brain 125:1760-1771.

Greenough, W.T., Klintsova, A.Y., Irwin, S.A., Galvez, R., Bates, K.E., and Weiler, I.J. 2001. Synaptic regulation of protein synthesis and the fragile $\mathrm{X}$ protein. Proc. Natl. Acad. Sci. USA. 98:7101-7106.

Hagerman, R.J., Van Housen, K., Smith, A.C., and McGavran, L. 1984a. Consideration of connective tissue dysfunction in the fragile X syndrome. Am. J. Med. Genet. 17:111-121.

Hagerman, R.J., and Synhorst, D.P. 1984b. Mitral valve prolapse and aortic dilatation in the fragile $\mathrm{X}$ syndrome. Am. J. Med. Genet. 17:123-131.

Hagerman, R.J., and Cronister, A. 1996. Fragile X Syndrome Diagnosis, Treatment, and Re- search. Baltimore, MD:Johns. Hopkins. Univ. Press. 481pp.

Hagerman, R.J., Leehey, M., Heinrichs, W., Tassone, F., Wilson, R., Hills, J., Grigsby, J., Gage, B., and Hagerman, P.J. 2001. Intention tremor parkinsonism, and generalized brain atrophy in male carriers of fragile X. Neurol. 57:127130.

Hinds, H.L., Ashley, C.T., Sutcliffe, J.S., Nelson, D.L., Warren, S.T., Housman, D.E., and Schalling, M. 1993. Tissue specific expression of FMR-1 provides evidence for a functional role in fragile $X$ syndrome. Nat. Genet. 3:36-43.

Hinton, V.J., Brown, W.T., Wisniewski, K., and Rudelli, R.D. 1991. Analysis of neocortex in three males with the fragile X syndrom. Am. J. Med. Genet. 41:289-294.

Hirst, M., Grewal, P., Flannery, A., Slatter, R., Maher, E., Barton, D., Fryns, J.P., and Davies, K. 1995. Two new cases of FMR1 deletion associated with mental impairment. Am. J. Hum. Genet. 56:67-74.

Hollmann, M., and Heinemann, S. 1994. Cloned glutamate receptors. Annu. Rev. Neurosci. 17:31-108.

Huber, K.M., Gallagher, S.M., Warren, S.T., and Bear, M.F. 2002. Altered synaptic plasticity in a mouse model of 
fragile $X$ mental retardation. Proc. Natl. Acad. Sci. USA. 99:7746-7750.

Hummel T, Krukkert K, Roos J, Davis G, Klambt C. 2000. Drosophila Futsch/22C10 is a MAP1B-like protein required for dendritic and axonal development. Neuron 26:357-370.

Inglis, F.M., Crockett, R., Korada, S., Abraham, W.C., Hollmann, M., and Kalb, R.G. 2002. The AMPA receptor subunit GluR1 regulates dendritic architecture of motor neurons. J. Neurosci. 22:8042-8051.

Irwin, S.A., Galvez, R., and Greenough, W.T. 2000. Dendritic spine structural anomalies in fragile-X mental retardation syndrome. Cereb. Cortex. 10:1038-1044.

Irwin, S.A., Patel, B., Idupulapati, M., Harris, J.B., Crisostomo, R.A., Larsen, B.P., Kooy, F., Willems, P.J., Cras, P., Kozlowski, P.B., Swain, R.A., Weiler, I.J., and Greenough, W.T. 2001. Abnormal dendritic spine characteristics in the temporal and visual cortices of patients with fragile-X syndrome: a quantitative examination. Am. J. Med. Genet. 98:161-167.

Ishizuka, A., Siomi, M.C., and Siomi, H.. 2002. A Drosophila fragile $X$ protein interacts with components of RNAi and ribosomal proteins. Genes. Dev. 16:2497-2508.

Khandjian, E.W., Corbin, F., Woerly, S., Rousseau, F. 1996. The fragile $X$ mental retardation protein is associated with ribosomes. Nat Genet. 12:91-93.

Kaytor, M.D., and Orr, H.T. 2001. RNA targets of the fragile X protein. Cell 107:555-557.

Kawasaki, H., and Taira, K. 2003. Hes1 is a target of microRNA-23 during retinoic-acid-induced neuronal differentiation of NT2 cells. Nature 423:838-842.

Kenneson, A., Zhang, F., Hagedorn, C.H., and Warren, S.T. 2001. Reduced FMRP and increased FMR1 transcription is proportionally associated with CGG repeat number in intermediate-length and premutation carriers. Hum. Mol. Genet. 10:1449-1454.

Kiledjian, M., and Dreyfuss, G. 1992. Primary structure and binding activity of the hnRNP $U$ protein: binding RNA through RGG box. EMBO J. 11:2655-2664.

Kobayashi, K., Kuroda, S., Fukata, M., Nakamura, T., Nagase, T., Nomura, N., Matsuura, Y., YoshidaKubomura, N., Iwamatsu, A., and Kaibuchi. 1998. p140Sra-1 (specifically Rac1-associated protein) is a novel specific target for Rac1 small GTPase. J. Biol. Chem. 273:291-295.

Kohrmann, M., Luo, M., Kaether, C., DesGroseillers, L., Dotti, C.G., and Kiebler, M.A. 1999. Microtubuledependent recrutment of Staufen-green fluorescent protein into large RNA-containing granules and subsequent dendritic transport in living hippocampal neurons. Mol. Biol. Cell 10:2945-2953.

Laggerbauer, B., Ostareck, D., Keidel, E.M., OstareckLederer, A., and Fischer, U. 2001. Evidence that fragile $X$ mental retardation protein is a negative regulator of translation. Hum. Mol. Genet. 10:329-338.

Lapeyre, B., Mariottini, P., Mathieu, C., Ferrer, P., Amaldi, F., Amalric, F., and Caizergues-Ferrer, M. 1990. Molecular cloning of Xenopus brillarin, a conserved U3 small nuclear ribonucleoprotein recognized by antisera from humans with autoimmune disease. Mol. Cell. Biol. 10:430-434.

Lee, W. C., Xue, Z., and Mélèse, T. 1991. The NSR1 gene encodes a protein that speci cally binds nuclear localization sequences and has two RNA recognition motifs. J. Cell Biol. 113:1-12.

Lengyel, J., Guy, C., Leong, V., Borge, S., and Rice, S.A. 2002. Mapping of functional regions in the amino-terminal portion of the herpes simplex virus ICP27 regulatory protein: importance of the leucine-rich nuclear export signal and RGG Box RNA-binding domain. J. Virol. 76:11866-1179.

Lewis, H.A., Musunuru, K., Jensen, K.B., Edo, C., Chen, H., Darnell, R.B., and Burley, S.K. 2000. Sequencespecific RNA binding by a Nova KH domain: implications for paraneoplastic disease and the fragile $X$ syndrome. Cell 100:323-332.

Li, Z., Zhang, Y., Ku, L., Wilkinson, K.D., Warren, S.T., and Feng, Y. 2001. The fragile $X$ mental retardation protein inhibits translation via interacting with mRNA. Nucleic. Acids. Res. 29:2276-2283.

Li, J., Pelletier, M.R., Perez Velazquez, J.L., and Carlen, P.L. 2002. Reduced cortical synaptic plasticity and GluR1 expression associated with fragile $\mathrm{X}$ mental retardation protein deficiency. Mol. Cell. Neurosci. 19:138-151.

Loehr, J.P., Synhorst, D.P., Wolfe, R.R., and Hagerman, R.J. 1986. Aortic root dilatation and mitral valve prolapse in the fragile X syndrome. Am. J. Med. Genet. 23:189194.

Lubs, H.A. 1969. A marker X chromosome. Am. J. Hum. Genet. 21:231-44.

Mallardo M, Deitinghoff A, Muller J, Goetze B, Macchi P, Peters C, Kiebler MA. 2003. Isolation and characterization of Staufen-containing ribonucleoprotein particles from rat brain. Proc Natl Acad Sci U S A. 100:2100-2105.

Malter, H.E., Iber, J.C., Willemsen, R., de Graaff, E., Tarleton, J.C., Leisti, J., Warren, S.T., and Oostra, B.A. 1997. Characterization of the full fragile $X$ syndrome mutation in fetal gametes. Nat. Genet. 15:165-169.

Martin, J., and Bell, J. 1943. A pedigree of mental defect showing sex-linkage. Arch. Neurol. Psychiat. 6:154-157. Maurer-Stroh, S., Dickens, N.J., Hughes-Davies, L., Kouzarides, T., Eisenhaber, F., and Ponting, C.P. 2003. TheTudor domain 'Royal Family': Tudor, plant Agenet, Chromo, PWWP and MBT domains. Trends Biochem. Sci. 28:69-74.

Mazroui, R., Huot, M.E., Tremblay, S., Filion, C., Labelle, Y., and Khandjian, E.W. 2002. Trapping of messenger RNA by Fragile $X$ Mental Retardation protein into cytoplasmic granules induces translation repression. Hum. Mol. Genet. 11:3007-3017.

Meijer, H., de Graaff, E., Merckx, D.M., Jongbloed, R.J., de Die-Smulders, C.E., Engelen, J.J., Fryns, J.P., Curfs, P.M., and Oostra, B.A. 1994. A deletion of $1.6 \mathrm{~kb}$ proximal to the CGG repeat of the FMR1 gene causes the clinical phenotype of the fragile X syndrome. Hum. Mol. Genet. 3:615-620.

Merenstein, S.A., Sobesky, W.E., Taylor, A.K., Riddle, J,E., Tran, H.X., and Hagerman, R.J. 1996. Molecular-clinical correlations in males with an expanded FMR1 mutation. Am. J. Med. Genet. 1996 64:388-394.

Michelotti, E.F., Michelotti, G.A., Aronsohn, A.I., and Levens, D. 1996. Heterogeneous nuclear ribonucleoprotein $\mathrm{K}$ is a transcription factor. Mol. Cell. Biol. 16:2350-2360. 
Mila', M., Castellvi-Bel, S., Sanchez, A., Barcelo, A., Badenas, C., Mallolas, J., and Estivill, X. 2000. Rare variants in the promoter of the fragile $X$ syndrome gene (FMR1). Mol. Cell. Probes. 14: 115-119.

Miyashiro, K.Y., Beckel-Mitchener, A., Purk, T.P., Becker, K.G., Barret, T., Liu, L., Carbonetto, S., Weiler, I.J., Greenough, W.T., and Eberwine, J. 2003. RNA cargoes associating with FMRP reveal deficits in cellular functioning in Fmr1 null mice. Neuron 37:417-431.

Morales, J., Hiesinger, P.R., Schroeder, A.J., Kume, K., Verstreken, P., Jackson, F.R., Nelson, D.L., and Hassan, B.A. 2002. Drosophila fragile $X$ protein, DFXR, regulates neuronal morphology and function in the brain. Neuron 34:961-972.

Muddashetty, R., Khanam, T., Kondrashov, A., Bundman, M., lacoangeli, A., Kremerskothen, J., Duning, K., Barnekow, A., Huttenhofer, A., Tiedge, H., and Brosius, J. 2002. Poly(A)-binding protein is associated with neuronal $\mathrm{BC} 1$ and $\mathrm{BC} 200$ ribonucleoprotein particles. J. Mol. Biol. 321:433-445.

Musco, G., Stier, G., Joseph, C., Castiglione Morelli, M.A., Nilges, M., Gibson, T.J., and Pastore, A. 1996. Threedimensional structure and stability of the $\mathrm{KH}$ domain: molecular insights into the fragile $X$ syndrome. Cell 85:237-245.

Musumeci, S.A., Hagerman, R.J., Ferri, R., Bosco, P., Dalla Bernardina, B., Tassinari, C.A., De Sarro, G.B., and Elia, M. 1999. Epilepsy and EEG findings in males with fragile X syndrome. Epilepsia 40:1092-1099.

Nakayama, A.Y., and Luo, L. 2000. Intracellular signaling pathways that regulate dendritic spine morphogenesis. Hippocampus 10:582-586.

Nichols, R.C., Wang, X.W., Tang, J., Hamilton, B.J., High, F.A., Herschman, H.R., and Rigby, W.F. 2000. The RGG domain in hnRNP A2 affects subcellular localization. Exp. Cell. Res. 256:522-532.

Nimchinsky, E.A., Oberlander, A.M., and Svoboda, K. 2001 Abnormal development of dendritic spines in FMR1 knock-out mice. J. Neurosci. 21:5139-5146.

Nolin, S.L., Brown, W.T., Glicksman, A., Houck, G.E., Gargano, A.D., Sullivan, A., Biancalana, V., BrondumNielsen K., Hjalgrim, H., Holinski-Feder, E., Kooy, F., Longshore, J., Macpherson, J., Mandel, J., Matthijs, G., Rousseau, F., Steinbach, P., Vaisanen, M., von Koskull, H., and Sherman, S.L. 2003. Expansion of the FragileX CGG repeat in females with premutation or intermediate alleles. Am. J. Hum. Genet. 72:454-464.

Oberle', I., Rousseau, F., Heitz, D., Krez, C., Devys, D., Hanauer, A., Boue, J., Bertheas, M.F., and Mandel, J.L. 1991. Instability of a 550-base pair DNA segment and abnormal methylation in fragile $X$ sindrome. Science 252:1097-1102.

O'Donnell, W.T., and Warren, S.T. 2002. A decade of molecular studies of fragile $x$ syndrome. Annu. Rev. Neurosci. 25:315-338.

Ohashi S, Kobayashi S, Omori A, Ohara S, Omae A, Muramatsu T, Li Y, Anzai K. 2000. The single-stranded DNA- and RNA-binding proteins pur alpha and pur beta link BC1 RNA to microtubules through binding to the dendrite-targeting RNA motifs. J. Neurochem. 75:17811790.
Ohashi, S., Koike, K., Omori, A., Ichinose, S., Ohara, S., Kobayashi, S., Sato, T.A., and Anzai, K. 2002. Identification of mRNA/protein (mRNP) complexes containing Puralpha, mStaufen, fragile $X$ protein, and myosin $\mathrm{Va}$ and their association with rough endoplasmic reticulum equipped with a kinesin motor. J. Biol. Chem. 277:37804-37810.

Oostra, B.A. 2002. Functions of the fragile $X$ protein. Trends. Mol. Med. 8:102-103.

Opitz, J.M., Westphal, J.M., and Daniel, A. 1984. Discovery of a connective tissue dysplasia in the Martin-Bell syndrome. Am. J. Med. Genet. 17:101-109.

Ostroff, L.E., Fiala, J.C., Allwardt, B., and Harris, K.M. 2002. Polyribosomes redistribute from dendritic shafts into spines with enlarged synapses during LTP in developing rat hippocampal slices. Neuron 35:535-545.

Poncer, J.C., Esteban, J.A., and Malinow, R. 2002. Multiple mechanisms for the potentiation of AMPA receptormediated transmission by alpha-Ca2+/calmodulindependent protein kinase II. J. Neurosci. 22:4406-4411.

Price, D.K., Zhang, F., Ashley, C.T. Jr., and Warren, S.T. 1996. The chicken FMR1 gene is highly conserved with a CCT 5'-untranslated repeat and encodes an RNAbinding protein. Genomics 31:3-12.

Primerano, B., Tassone, F., Hagerman, R.J., Hagerman, P., Amaldi, F., and Bagni, C. 2002. Reduced FMR1 mRNA translation efficiency in Fragile $X$ patients with premutations. RNA 8:1482-1488.

Purpura, D.P. 1974. Dendritic spine "dysgenesis" and mental retardation. Science186:1126-1128.

Roche, K.W., O'Brien, R.J., Mammen, A.L., Bernhardt, J., and Huganir, R.L. 1996. Characterization of multiple phosphorylation sites on the AMPA receptor GluR1 subunit. Neuron 16:1179-1188.

Roos, J., Hummel, T., Ng, N., Klambt, C., and Davis, G.W. 2000. Drosophila Futsch regulates synaptic microtubule organization and is necessary for synaptic growth. Neuron 26:371-382.

Rousseau, F., Rouillard, P., Morel, M.L., Khandjian, E.W., and Morgan, K. 1995. Prevalence of carriers of premutation-size alleles of the FMRI gene and implications for the population genetics of the fragile $X$ syndrome. Am. J. Hum. Genet. 57:1006-1018.

Rozhdestvensky, T.S., Kopylov, A.M., Brosius, J., and Huttenhofer, A. 2001. Neuronal BC1 RNA structure: evolutionary conversion of a tRNA(Ala) domain into an extended stem-loop structure. RNA 7:722-730.

Rudelli, R.D., Brown, W.T., Wisniewski, K., Jenkins, E.C., Laure-Kamionowska, M., Connell, F., and Wisniewski, H.M. 1985. Adult fragile $X$ syndrome. Cliniconeuropathologic findings. Acta. Neuropathol. Berl. 67:289295.

Sabaratnam, M., Vroegop, P.G., and Gangadharan, S.K. 2001. Epilepsy and EEG findings in 18 males with fragile $X$ syndrome. Seizure 10:60-63.

Sala C, Futai K, Yamamoto K, Worley PF, Hayashi Y, Sheng M. 2003. Inhibition of dendritic spine morphogenesis and synaptic transmission by activity-inducible protein Homer1a. J Neurosci. 23:6327-37.

Sandri-Goldin, R.M. 1998. ICP27 mediates HSV RNA export by shuttling through a leucine-rich nuclear export 
signal and binding viral intronless RNAs through an RGG motif. Genes. Dev. 12:868-879.

Schaeffer, C., Bardoni, B., Mandel, J.L., Ehresmann, B., Ehresmann, C., and Moine, H. 2001. The fragile X mental retardation protein binds specifically to its mRNA via a purine quartet motif. EMBO J. 20:4803-4813.

Schenck, A., Bardoni, B., Moro, A., Bagni, C., and Mandel, J.L. 2001. A highly conserved protein family interacting with the fragile $X$ mental retardation protein (FMRP) and displaying selective interactions with FMRP-related proteins FXR1P and FXR2P. Proc. Natl. Acad. Sci. USA. 98:8844-8849.

Schenck, A., Van de Bor, V., Bardoni, B., and Giangrande, A. 2002. Novel features of dFMR1, the Drosophila orthologue of the fragile $\mathrm{X}$ mental retardation protein. Neurobiol. Dis. 11:53-63.

Schenck, A., Bardoni, B., Langmann, C., Harden, N., Mandel, J.L., and Giangrande, A. 2003. CYFIP/Sra-1 Controls Neuronal Connectivity in Drosophila and Links the Rac1 GTPase Pathway to the Fragile X Protein. Neuron 38:887-898.

Shtang, S., Perry, M.D., Percy, M.E. 1999. Search for a Caenorhabditis elegans FMR1 homologue: identification of a new putative RNA-binding protein (PRP-1) that hybridizes to the mouse FMR1 double $\mathrm{K}$ homology domain. Am. J. Med. Genet. 84:283-5.

Siomi, H., Matunis, M.J., Michael, W.M., and Dreyfuss, G. 1993. The pre-mRNA binding $K$ protein contains a novel evolutionarily conserved motif. Nucleic. Acids. Res. 21:1193-1198.

Siomi, H., Choi, M., Siomi, M.C., Nussbaum, R.L., and Dreyfuss, G. 1994. Essential role for KH domains in RNA binding: impaired RNA binding by a mutation in the $\mathrm{KH}$ domain of FMR1 that causes fragile $X$ syndrome. Cell 77:33-39.

Siomi, M., Siomi, H., Sauer, W.H., Srinivasan, S., Nussbaum, R.L., and Dreyfuss, G. 1995. FXR1, an autosomal homolog of the fragile $X$ mental retardation gene. EMBO J. 14:2401-2408.

Siomi, M.C., Zhang, Y., Siomi, H., and Dreyfuss, G. 1996. Specific sequences in the fragile $X$ syndrome protein FMR1 and the FXR proteins mediate their binding to 605 ribosomal subunits and the interactions among them. Mol. Cell. Biol. 16:3825-3832.

Sittler A, Devys D, Weber C, Mandel JL. 1996. Alternative splicing of exon 14 determines nuclear or cytoplasmic localisation of fmr1 protein isoforms. Hum. Mol. Genet. 5:95-102.

Snyder EM, Philpot BD, Huber KM, Dong X, Fallon JR, Bear MF. 2001. Internalization of ionotropic glutamate receptors in response to mGluR activation. Nat. Neurosci. 4:1079-1085.

Song I, Huganir RL. 2002. Regulation of AMPA receptors during synaptic plasticity. Trends Neurosci. 11:578-88.

Stevenson, R.E., Schwartz, C.E., and Schroer, R.J. 2000. $X$-Linked Mental Retardation. Oxford Univ. Press.

Steward, O., Bakker, C.E., Willems, P.J., and Oostra, B.A. 1998. No evidence for disruption of normal patterns of mRNA localization in dendrites or dendritic transport of recently synthesized mRNA in FMR1 knockout mice, a model for human fragile- $X$ mental retardation syndrome. Neuroreport 9:477-481.
Steward, O., and Schuman, E.M. 2001. Protein synthesis at synaptic sites on dendrites. Annu. Rev. Neurosci. 24:299-325.

Sung, Y.J., Conti, J., Currie, J.R., Brown, W.T., and Denman, R.B. 2000. RNAs that interact with the fragile $X$ syndrome RNA binding protein FMRP. Biochem. Biophys. Res. Commun. 275:973-980.

Sutcliffe, J.S., Nelson, D.L., Zhang, F., Pieretti, M., Caskey, C.T., Saxe, D., and Warren, S.T. 1992. DNA methylation represses FMR-1 transcription in fragile $X$ syndrome. Hum. Mol. Genet. 1:397-400.

Sutherland, G.R. 1977. Fragile sites on human chromosomes: demonstration of their dependence on the type of tissue culture medium. Science 197:265-266.

Tamanini, F., Van Unen, L., Bakker, C., Sacchi, N., Galjaard, H., Oostra, B.A., and Hoogeveen, A.T. 1999. Oligomerization properties of fragile-X mental-retardation protein (FMRP) and the fragile-X-related proteins FXR1P and FXR2P. Biochem. J. 343:517-523.

Tan, S.E., Wenthold, R.J., and Soderling, T.R. 1994. Phosphorylation of AMPA-type glutamate receptors by calcium/calmodulin-dependent protein kinase II and protein kinase $\mathrm{C}$ incultured hippocampal neurons. J. Neurosci. 14:1123-1129.

Tassone, F., Hagerman, R.J., Taylor, A.K., Gane, L.W., Godfrey, T.E., and Hagerman, P.J. 2000a. Elevated levels of FMR1 mRNA in carrier males: a new mechanism of involvement in the fragile-X syndrome. Am. J. Hum. Genet. 66:6-15.

Tassone, F., Hagerman, R.J., Loesch, D.Z., Lachiewicz, A., Taylor, A.K., and Hagerman, P.J. 2000b. Fragile $X$ males with unmethylated, full mutation trinucleotide repeat expansions have elevated levels of FMR1 messenger RNA. Am. J. Med. Genet. 94:232-236.

Turner, G., Daniel, A., and Frost, M. 1980. X-linked mental retardation, macro-orchidism, and the $\mathrm{Xq27}$ fragile site. J. Pediatr. 96:837-841.

Uzielli, M.L., Guarducci, S., Lapi, E., Cecconi, A., Ricci, U., Ricotti, G., Biondi, C., Scarselli, B., Vieri, F., Scarnato, P., Gori, F, and Sereni A. 1999. Premature ovarian failure (POF) and fragile $X$ premutation females: from POF to to fragile $X$ carrier identification, from fragile $X$ carrier diagnosis to POF association data. Am. J. Med. Genet. 84:300-303.

Vanderklish, P.W., and Edelman, G.M. 2002. Dendritic spines elongate after stimulation of group 1 metabotropic glutamate receptors in cultured hippocampal neurons. Proc Natl Acad Sci U S A. 99:1639-44.

Verheij, C., Bakker, C.E., de Graaff, E., Keulemans, J., Willemsen, R., Verkerk, A.J., Galjaard, H., Reuser, A.J., Hoogeveen, A.T., and Oostra, B.A. 1993. Characterization and localization of the FMR-1 gene product associated with fragile $X$ syndrome. Nature 363:722-724.

Verkerk, A.J., Pieretti, M., Sutcliffe, J.S., Fu, Y.H., Kuhl, D.P., Pizzuti, A., Reiner, O., Richards, S., Victoria, M.F., Zhang, F.P., et al. 1991. Identification of a gene (FMR-1) containing a CGG repeat coincident with a breakpoint cluster region exhibiting length variation in fragile $X$ syndrome. Cell 65:905-914.

Verkerk, A.J., de Graaff, E., De Boulle, K., Eichler, E.E., Konecki, D.S., Reyniers, E., Manca, A., Poustka, A., 
Willems, P.J., Nelson, D.L., et al. 1993. Alternative splicing in the fragile $X$ gene FMR1. Hum. Mol. Genet. 2:1348.

Yu, S., Pritchard, M., Kremer, E., Lynch, M., Nancarrow, J., Baker, E., Holman, K., Mulley, J.C., Warren, S.T., Schlessinger, D., et al. 1991. Fragile X genotype characterized by an unstable region of DNA. Science 252:1179-1181.

Wan, L., Dockendorff, T.C., Jongens, T.A., and Dreyfuss, G. 2000. Characterization of dFMR1, a Drosophila melanogaster Homolog of the Fragile $X$ Mental Retardation Protein. Mol. Cell. Biol. 20:8536-8547.

Wang, H., lacoangeli, A., Popp, S., Muslimov, I.A., Imataka, H., Sonenberg, N., Lomakin, I.B., and Tiedge, H. 2002. Dendritic BC1 RNA: functional role in regulation of translation initiation. J. Neurosci. 22:10232-10241.

Weiler, I.J., Irwin, S.A., Klintsova, A.Y., Spencer, C.M., Brazelton, A.D., Miyashiro, K., Comery, T.A., Patel, B., Eberwine, J., and Greenough, W.T. 1997. Fragile X mental retardation protein is translated near synapses in response to neurotransmitter activation. Proc. Natl. Acad. Sci. USA. 94:5395-5400.

Willemsen, R., Hoogeveen-Westerveld, M., Reis, S., Holstege, J., Severijnen, L.A., Nieuwenhuizen, I.M., Schrier, M., Van Unen, L., Tassone, F., Hoogeveen, A.T., Hagerman, P.J., Mientjes, E.J., and Oostra, B.A. 2003. The FMR1 CGG repeat mouse displays ubiquitin-positive intranuclear neuronal inclusions; implications for the cerebellar tremor/ataxia syndrome. Hum. Mol. Genet. 12:949-959.

Wohrle, D., Kotzot, D., Hirst, M.C., Manca, A., Korn, B., Schmidt, A., Barbi, G., Rott, H.D., Poustka, A., Davies, K.E., et al. 1992. A microdeletion of less than $250 \mathrm{~kb}$, including the proximal part of the FMR-I gene and the fragile- $X$ site, in a male with the clinical phenotype of fragile-X syndrome. Am. J. Hum. Genet. 51:299-306.

Zalfa, F., Giorgi, M., Primerano, B., Moro, A., Di Penta, A., Reis, S., Oostra, B.A., and Bagni, C. 2003. The Fragile $X$ Syndrome Protein FMRP Associates with BC1 RNA and Regulates the Translation of Specific mRNAs at Synapses. Cell 112:317-327.

Zhang, Y., O'Connor, J.P., Siomi, M.C., Srinivasan, S., Dutra, A., Nussbaum, R.L., and Dreyfuss, G. 1995. The Fragile X Mental Retardation Syndrome protein interacts with novel homologs FXR1 and FXR2. EMBO J. 14:53585366.

Zhang, S., and Grosse, F. 1997. Domain structure of human nuclear DNA helicase II (RNA helicase A). J. Biol. Chem. 272:11487-1194.

Zhang, Y.Q., Bailey, A.M., Matthies, H.J., Renden, R.B., Smith, M.A., Speese, S.D., Rubin, G.M., and Broadie, K. 2001. Drosophila fragile $X$-related gene regulates the MAP1B homolog Futsch to control synaptic structure and function. Cell 107:591-603. 


\section{Further Reading}

Caister Academic Press is a leading academic publisher of advanced texts in microbiology, molecular biology and medical research. Full details of all our publications at caister.com

- MALDI-TOF Mass Spectrometry in Microbiology Edited by: M Kostrzewa, S Schubert (2016) www.caister.com/malditof

- Aspergillus and Penicillium in the Post-genomic Era Edited by: RP Vries, IB Gelber, MR Andersen (2016) www.caister.com/aspergillus2

- The Bacteriocins: Current Knowledge and Future Prospects Edited by: RL Dorit, SM Roy, MA Riley (2016)

www.caister.com/bacteriocins

- Omics in Plant Disease Resistance Edited by: V Bhadauria (2016) www.caister.com/opd

- Acidophiles: Life in Extremely Acidic Environments Edited by: R Quatrini, DB Johnson (2016) www.caister.com/acidophiles

- Climate Change and Microbial Ecology: Current Research and Future Trend

Edited by: J Marxsen (2016)

www.caister.com/climate

- Biofilms in Bioremediation: Current Research and Emerging Technologies

Edited by: G Lear (2016)

www.caister.com/biorem

- Microalgae: Current Research and Applications Edited by: MN Tsaloglou (2016) www.caister.com/microalgae

- Gas Plasma Sterilization in Microbiology: Theory, Applications, Pitfalls and New Perspectives Edited by: H Shintani, A Sakudo (2016) www.caister.com/gasplasma

- Virus Evolution: Current Research and Future Directions Edited by: SC Weaver, M Denison, M Roossinck, et al. (2016) www.caister.com/virusevol

- Arboviruses: Molecular Biology, Evolution and Control Edited by: N Vasilakis, DJ Gubler (2016) www.caister.com/arbo

- Shigella: Molecular and Cellular Biology Edited by: WD Picking, WL Picking (2016) www.caister.com/shigella

-Aquatic Biofilms: Ecology, Water Quality and Wastewater Treatment

Edited by: AM Romaní, H Guasch, MD Balaguer (2016)

www.caister.com/aquaticbiofilms

- Alphaviruses: Current Biology

Edited by: S Mahalingam, L Herrero, B Herring (2016)

www.caister.com/alpha

- Thermophilic Microorganisms

Edited by: F Li (2015)

www.caister.com/thermophile
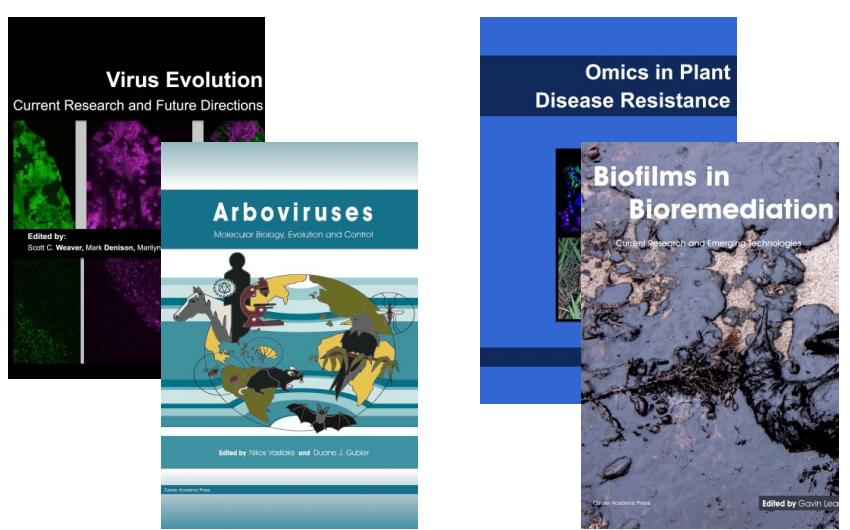
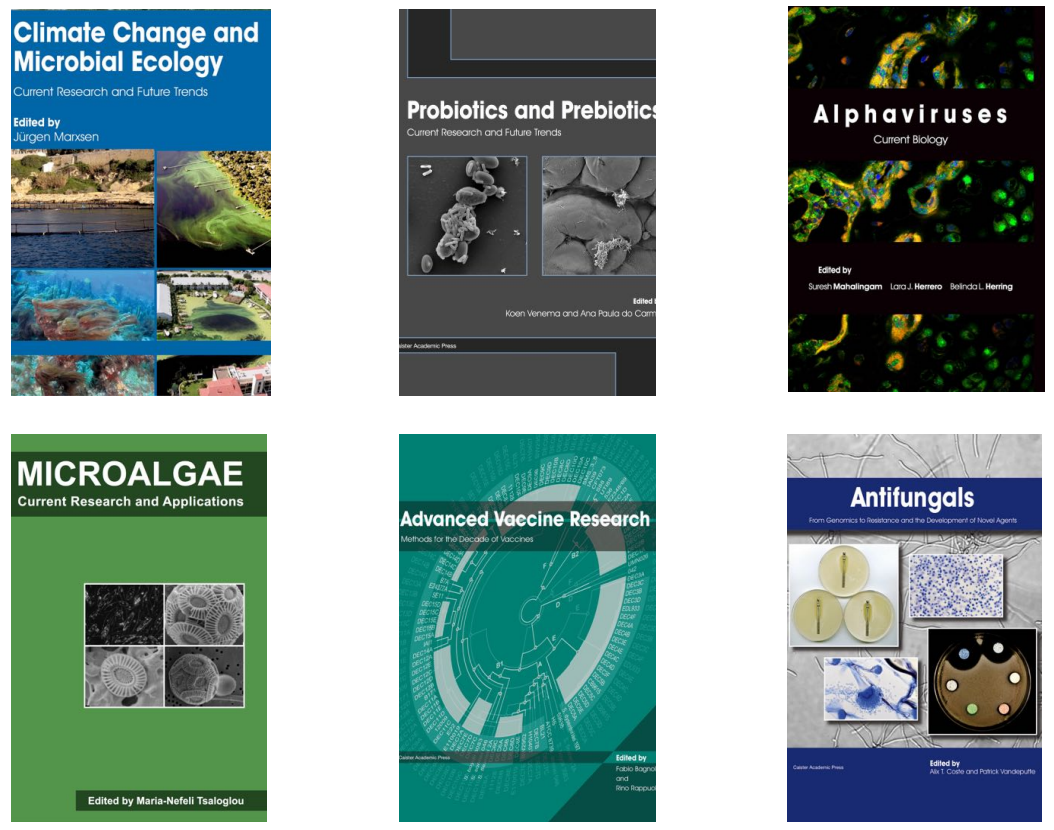

- Flow Cytometry in Microbiology: Technology and Applications Edited by: MG Wilkinson (2015) www.caister.com/flow

- Probiotics and Prebiotics: Current Research and Future Trends Edited by: K Venema, AP Carmo (2015) www.caister.com/probiotics

- Epigenetics: Current Research and Emerging Trends Edited by: BP Chadwick (2015) www.caister.com/epigenetics2015

- Corynebacterium glutamicum: From Systems Biology to Biotechnological Applications

Edited by: A Burkovski (2015)

www.caister.com/cory2

- Advanced Vaccine Research Methods for the Decade of Vaccines

Edited by: F Bagnoli, R Rappuoli (2015)

www.caister.com/vaccines

- Antifungals: From Genomics to Resistance and the Development of Novel Agents

Edited by: AT Coste, P Vandeputte (2015)

www.caister.com/antifungals

- Bacteria-Plant Interactions: Advanced Research and Future Trends Edited by: J Murillo, BA Vinatzer, RW Jackson, et al. (2015) www.caister.com/bacteria-plant

\section{- Aeromonas}

Edited by: J Graf (2015)

www.caister.com/aeromonas

- Antibiotics: Current Innovations and Future Trends

Edited by: S Sánchez, AL Demain (2015)

www.caister.com/antibiotics

- Leishmania: Current Biology and Contro Edited by: S Adak, R Datta (2015) www.caister.com/leish2

- Acanthamoeba: Biology and Pathogenesis (2nd edition) Author: NA Khan (2015)

www.caister.com/acanthamoeba2

- Microarrays: Current Technology, Innovations and Applications Edited by: Z He (2014)

www.caister.com/microarrays2

- Metagenomics of the Microbial Nitrogen Cycle: Theory, Methods and Applications

Edited by: D Marco (2014)

www.caister.com/n2 